\author{
Economics Working Paper Series
}

2021/002

\title{
Real Estate and Construction Sector Dynamics Over the Business Cycle
}

\author{
Kostas Vasilopoulos and William J. Tayler
}

The Department of Economics

Lancaster University Management School

Lancaster LA1 4YX

UK

(C) Authors

All rights reserved. Short sections of text, not to exceed two paragraphs, may be quoted without explicit permission, provided that full acknowledgement is given. 


\title{
Real Estate and Construction Sector Dynamics over the Business Cycle
}

\author{
Kostas Vasilopoulos*† and William J. Tayler ${ }^{\dagger}$ \\ ${ }^{\dagger}$ Department of Economics, Lancaster University Management School, Lancaster, UK
}

\begin{abstract}
This paper explores the property prices and investment dynamics over the business cycle when there is competition between households and firms for real estate. We introduce a construction sector into an RBC framework, which uses land, capital and labour to produce both commercial and residential real estate. This market structure activates a real estate substitution channel, where an increase in demand for residential real estate also increases the cost of producing commercial structures, which crowds out commercial real estate investment. In general, we find that the residential/commercial land allocation acts as an anchor for the allocation of its real estate investment counterpart; however, there are notable separations, particularly following the financial crisis where there was a simultaneous fall in residential and commercial investment. Our results indicate that whilst residential real estate prices were predominately driven by increases in its demand in the buildup to the financial crisis, the fall in demand for commercial real estate played a significant role in generating price falls for both types of real estate in the aftermath. Furthermore, falls in the overall supply of real estate played an important role in reducing real estate investment which put upward pressure on prices throughout the past two decades.
\end{abstract}

Key Words: Commercial Real Estate; Residential Real Estate; Real Estate Substitution; Land Prices; DSGE Models

JEL References: E32; E44; R21; R31

\footnotetext{
${ }^{*}$ Correspondence to: Kostas Vasilopoulos, Department of Economics, Lancaster University Management
} School, LA1 4YX, UK. E-mail: k.vasilopoulos@lancaster.ac.uk 


\section{Introduction}

Real estate is a significant component of the economy's capital stock and households' wealth, which serves as both a crucial input for producers and provider of residence for households. Investment in real estate can be categorised according to its use as either commercial or residential. ${ }^{1}$ Commercial real estate (henceforth CRE) typically accounts for around half of business assets (Nelson et al., 2000) whilst residential real estate (henceforth RRE) constitutes one-third of household net worth. As a result, the construction sector lies in an influential position as a major contributor to the business cycle (Case et al., 2000; Boldrin et al., 2013; Leamer, 2015; Head et al., 2014). Moreover, the construction sector works as a unique barometer of macroeconomic activity for both the demand and supply side of the economy. Specifically, CRE constitutes a significant factor of production at the firm level whilst RRE responds directly to the demand for residential housing over the business cycle. As a consequence, the competition for inputs that arise in the construction sector, such as land, labour and capital creates direct spillovers between the two types of real estate.

This paper builds a quantitative general equilibrium framework to investigate the implications of these competing demands faced by the construction sector for real estate price and investment dynamics over the business cycle. A closer look into the construction sector and the disaggregated construction spending for the US (Figure 1) reveals both commercial and residential spending growing in a similar way until 2001. However, after that period, and particularly following the two recession periods they behave quite differently. After the 2001 dot.com crisis, there was a fall in commercial spending. On the other hand, residential spending continued its upward trend until the onset of the 2007 financial crisis when it dived sooner and greater than commercial spending. Thus, depending on the source of macroeconomic fluctuation, these two types of real estate can potentially display quite different cyclical behaviours.

Figure 2 plots property prices alongside real estate investment. Since construction spending tracks the overall investment in real estate, i.e. the creation of new structures, investment seems to follows a very similar path. As was the case with construction spending, different types of real estate investment have quite different cyclic behaviours (Wheaton, 1999); this is particularly evident prior to the financial crisis. Analogous periods can also be considered, for example, during the 2nd energy crisis of 1982 and the aftermath of the early 1990s recession. In line

\footnotetext{
${ }^{1}$ Commercial real estate is property that is used exclusively for business-related purposes or to provide a workspace rather than as a living space, which would instead constitute residential real estate. Commercial investment consists of new construction and improvements to existing structures in commercial and health care buildings, manufacturing buildings, power and communications structures, and other structures. Residential investment includes new construction of single-family homes and multifamily homes and spending on other residential structures (Lally, 2009) - BEA Briefing
} 




Notes: Commercial construction spending (solid line) and residential construction spending (dotted line). Variables are in $\log$ units and normalised to the origin of the sample. The shaded bars mark the NBER recession dates. Private construction spending covers the dollar construction work carried out on new structures or improvements to existing structures. Data estimates include the cost of labour and materials, cost of architectural and engineering work, overhead costs, interest and taxes paid during construction, and contractor's profits. Source: data.gov

with the evidence of Rosen (1979); Roback (1982), and Gyourko (2009), property prices appear to comove contemporaneously and have similar time-series patterns. In particular, during the 2007-2008 financial crisis, both series displayed a sharp fall followed by a more gradual recovery. ${ }^{2}$

More recently, the move away from conventional office-based work towards home working due to the Covid-19 pandemic has only further emphasised the importance of understanding the properties and mechanisms behind these real estate co-movements. Whilst the long term implications for commercial and residential real estate demands are not fully apparent, there is a suggestion that many firms will adopt a more of a flexible home / office work based model reducing their demand for commercial premises. Moreover, to facilitate these changes local governments in major global cities such as New York and London have relaxed zoning restrictions to allow empty office space to be more easily converted for residential use.

To further understand the empirical relationship between residential and commercial real estate, we estimate a four-variable Bayesian vector autoregressive (BVAR) model following a RRE demand shock in Figure 3. The observables included in the model are RRE prices, RRE

\footnotetext{
${ }^{2}$ Land prices have followed a steady upward trend during the whole sample, which appears to drive both commercial and residential real estate prices (Davis and Heathcote, 2007; Glaeser and Ward, 2009; Gyourko et al., 2013).
} 
Prices

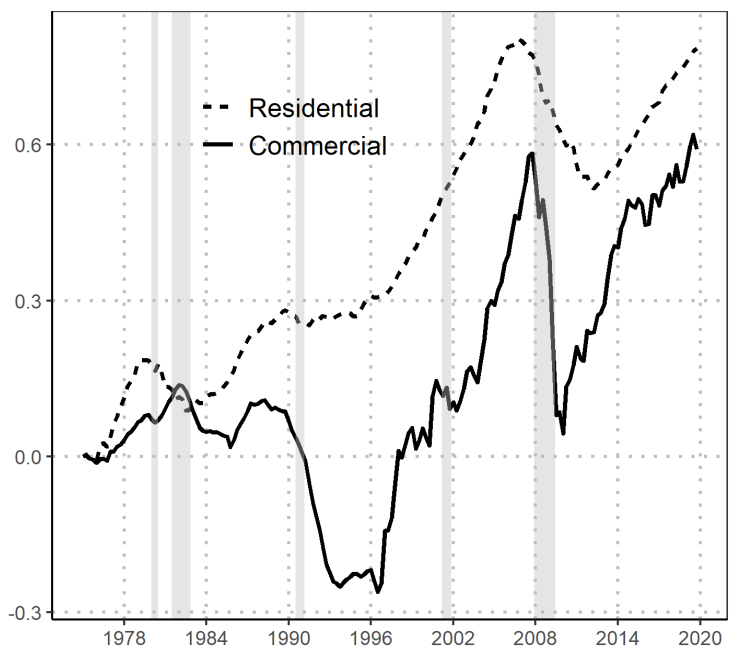

Investment

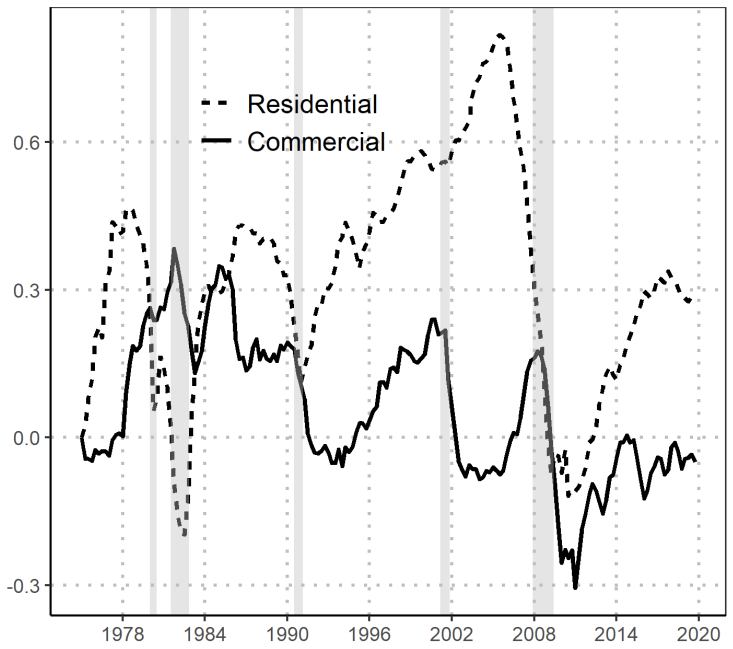

Notes: Real CRE prices/investment (solid line) and real RRE prices/investment (dashed line). All variables are in log units and normalized to the origin of the sample. The shaded bars mark the NBER recession dates.

investment, CRE investment, and CRE prices. ${ }^{3}$ We use a Flat Prior, and generate IRFs for an RRE price shock using recursive identification, where we order RRE prices first. Although the identification of the model may appear unguided by theory, it can approximate the effects of a RRE demand shock in a DSGE framework that represents an exogenous shift to housing preferences. ${ }^{4}$ A positive shock to the RRE price leads to a positive response of RRE investment. On the other hand, CRE investment has the opposite response, which indicates a substitution between the two real estate sectors, i.e. residential and commercial. Since property prices co-move, the CRE price increases following a positive shock to the RRE price.

The aim of this paper is to shed light on the mechanism behind the relationship between the price of residential and commercial real estate, and the substitution between residential and commercial investment outlined in Figure 3. We introduce a construction sector into a DSGE model, which undertakes the production of both commercial and residential real estate. Specifically, we introduce sectoral heterogeneity as in Iacoviello and Neri (2010), by differentiating

\footnotetext{
${ }^{3}$ In Appendix 1 there is a detailed descriptions of the data and the transformations used in the paper.

${ }^{4}$ Innovations in RRE price may simply reflect information already contained in other variables innovations. To address this possibility, we reorder the variables in the system such that RRE price is orthogonalized with respect to other variables (RRE price is ordered last). We find that, whether or not is first orthogonalized with respect to $\mathrm{CRE}$, the shape of the impulse responses remain identical. For robustness, we perform the same estimation with the Minnesota prior (Doan et al., 1984; Litterman, 1986), where we find similar results. Robustness checks are available in the Online Appendix.
} 

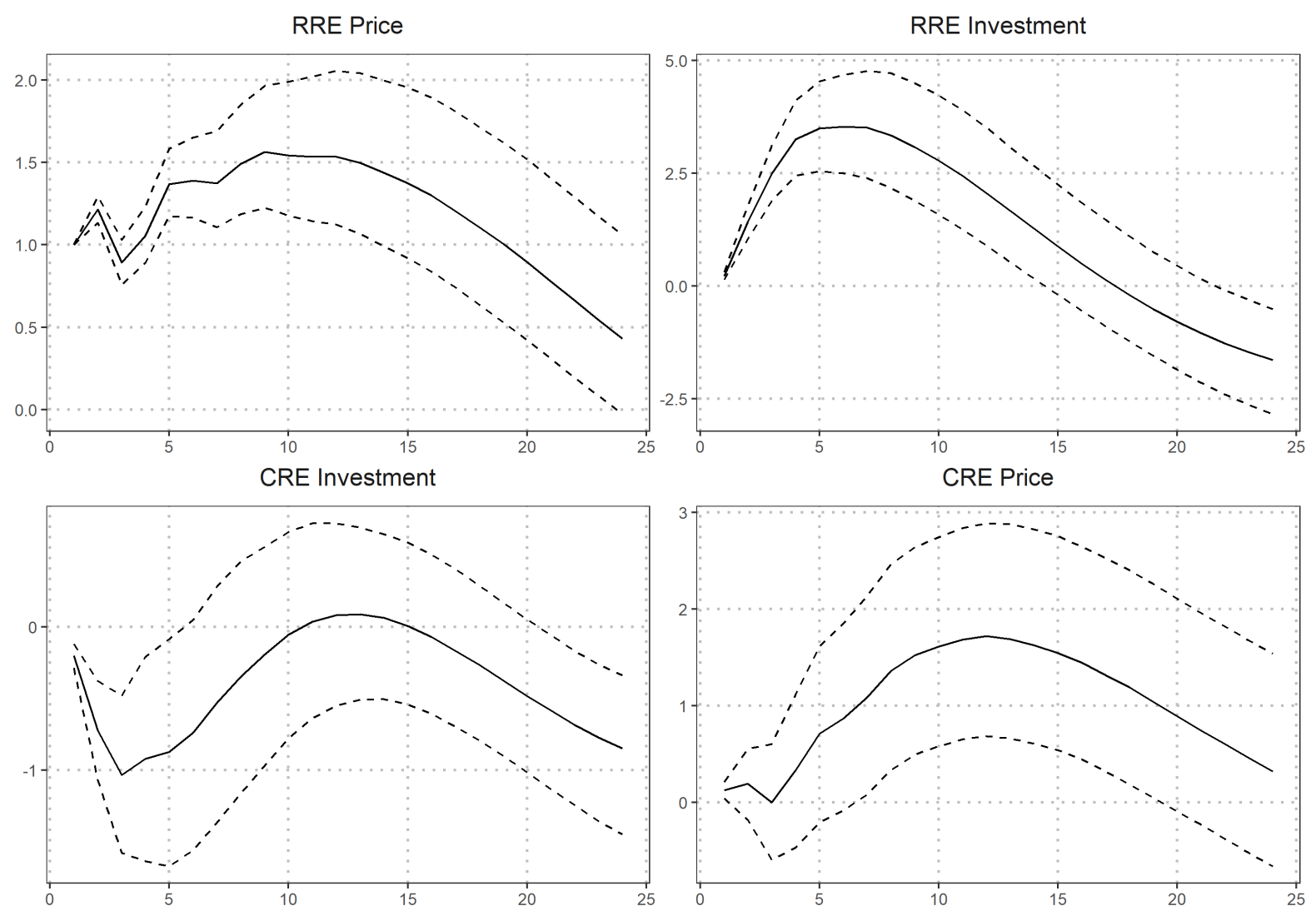

Notes: Impulse response to a positive shock to the residential real estate price from a recursive BVAR model with Diffuse Prior. Identification is achieved through Cholesky decomposition with the following ordering \{RRE Price, RRE Investment, CRE Investment, CRE Price\}, all in real terms. Solid lines represent the median estimated responses and dotted lines the $68 \%$ probability bands.

between two groups of entrepreneurs - consumption good and construction sector. To achieve this multi-sector entrepreneur structure, we disaggregate the capital stock into three components: consumption good, residential and commercial real estate. Whilst there is a growing literature whereby residential housing production allows households to consume both housing and nonhousing goods (Greenwood and Hercowitz, 1991; Benhabib et al., 1991; Chang, 2000; Davis and Heathcote, 2005; Fisher, 2007), we also allow the construction sector to facilitate the production of new commercial structures. In this way, we can analyse the interplay between commercial and residential real estate when there is both competition for inputs within the construction sector and competition for real estate between households and consumption good entrepreneurs.

According to Davis and Heathcote (2007), fluctuations in real estate values are primarily driven by changes in land prices, and land provides an important collateral value for business investment spending. As a result, we assume entrepreneurs in both groups face credit constraints 
in the spirit of Kiyotaki and Moore (1997), where firms finance investment spending by using the value of their inputs (besides labour) as collateral (Chaney et al., 2012; Bahaj et al., 2020). By doing so, there are positive co-movements between land prices and business investment as in Liu et al. (2013). However, the additional requirement of commercial and residential investment for construction, means that the dynamics and level of real estate prices can differ between commercial and residential production.

Our model is able to capture the substitution between commercial and residential investment, which is evident in the BVAR model in Figure 3. We refer to this mechanism as the real estate substitution channel. Following positive housing preference shocks the increase in demand for residential real estate also increases the cost of producing commercial structures, which reduces the quantity demanded by firms. In turn, this crowds out commercial real estate which affects the goods market in a similar way to an adverse aggregate supply shock. In contrast, following positive technology shocks this channel works in the opposite direction such that the increased demand for commercial real estate crowds out residential investment.

Real estate substitution encapsulates the land reallocation channel initially established by Liu et al. (2013), however, we claim that land use does not equate real estate investment. Land has a unique quality; it is fixed on aggregate, such that a demand driven increase in land use by one side of the real estate market must be reflected with an equivalent fall in land supply to the other. In contrast, real estate investment clearly follows its own law of motion, with the possibility that the residential and commercial counterparts could co-move. By introducing a construction sector where investment decisions depend upon not only land, but all of the inputs of real estate production, we are able to connect the dynamics of the two series. The simulated path of land shares and real estate investment indicate that in general, the residential/commercial land allocation acts as an anchor for the allocation of its real estate investment counterpart. However, this is by no means always the case and, in particular following the financial crisis, there was a substantial and persistent fall in both residential and commercial investment and a notable separation between real estate investment and land shares in each sector.

Our historical decomposition sheds light on the driving forces behind movements in the real estate market in particular the co-movement of CRE and RRE investment during the financial crisis. Our results indicate that increased demand for RRE drove much of the increase in RRE investment and prices in the build up to to the financial crisis (Iacoviello and Neri, 2010; Liu et al., 2013), which went some way to suppress CRE investment. However, the fall in demand for CRE played a significant role in generating price falls for both types of real estate in the aftermath of the crisis. Despite this, real estate substitution away from RRE did allow commercial investment to recover more rapidly. Furthermore, falls in the overall supply of real estate played an important role in reducing real estate investment and put upward pressure on 
real estate prices over the past two decades. This fall in supply was particularly notable in the aftermath of the financial crisis which helped offset some of the demand driven fall in prices.

The paper proceeds as follows. The next chapter describes the theoretical model. Section 3 reports the calibration and estimation details. Section 4 explains the properties of the model. Section 5 describes the unique role of land. Finally, Section 6 concludes.

\section{Model}

We consider an economy that consists of two types of agents: a representative household and an entrepreneur. The entrepreneur chooses to produce either consumption goods or build new property structures for residential or commercial purposes. The representative household's utility depends on consumption goods, housing, and leisure, while the entrepreneur's utility depends only on consumption goods. Consumption goods production requires labour, capital, and commercial real estate as inputs. Real estate investments require labour, capital, and land as inputs. Furthermore, the entrepreneur in both of these sectors needs external financing for investment spending. Imperfect contract enforcement implies that the entrepreneur's borrowing capacity is constrained by the value of their collateral assets. Because these assets vary depending upon the sector, collateral differs according to the type of production. Borrowing in the consumption good sector is constrained by the value of non-construction capital and the value of the commercial real estate, while the construction sector is constrained by the value of capital and land.

\subsection{Households}

There is a continuum of households indexed by $d \in[0,1]$. The representative household seeks to maximize its discounted, time separable lifetime utility. The utility function is given by

$$
E_{t} \sum_{t=0}^{\infty} \beta_{d}^{t} z_{t}\left\{\ln \left(C_{d, t}-\gamma_{d} C_{d, t-1}\right)+\chi_{t} \ln \left(H_{d, t}\right)-\frac{\psi_{t}}{1+\eta}\left(N_{c, t}^{1+\xi}+\left(N_{h c, t}+N_{h d, t}\right)^{1+\xi}\right)^{\frac{1+\eta}{1+\xi}}\right\},
$$

where $C_{d, t}$ denotes consumption, $H_{d, t}$ denotes the residential real estate stock, $N_{c, t}, N_{h c, t}$ and $N_{h d, t}$ denote labour hours in consumption good, commercial and residential real estate production, respectively. The parameter $\beta_{d} \in(0,1)$ is the household discount factor, $\gamma_{d}$ measures habits in consumption and parameters $\xi$ and $\eta$ measure the labour mobility among the different types of production and the inverse of the Frisch elasticity, respectively. The terms $z_{t}$ and $\psi_{t}$ capture shocks in intertemporal preference and labour supply, respectively. The parameter $\chi_{t}$ shifts housing preferences away from consumption and leisure towards residential real estate. The shock processes follow

$$
\ln z_{t}=\rho_{z} \ln z_{t-1}+\sigma_{z} \epsilon_{z, t}, \quad \ln \psi_{t}=\rho_{\psi} \ln \psi_{t-1}+\sigma_{\psi} \epsilon_{\psi, t}
$$




$$
\ln \chi_{t}=\left(1-\rho_{\chi}\right) \ln \bar{\chi}+\rho_{\chi} \ln \chi_{t-1}+\sigma_{\chi} \epsilon_{\chi, t},
$$

where $\sigma_{z}, \sigma_{\psi}, \sigma_{\chi}$ are the standard deviations of the innovation, and $\epsilon_{z, t}, \epsilon_{\psi, t}, \epsilon_{\chi, t}$ are independent and identically distributed (i.i.d) normal processes.

The disutility of labour follows Horvath (2000) and Iacoviello and Neri (2010) specification that allows for imperfect labour mobility among sectors. The household allocate labour resources to the productive activities, where for $\xi \geq 0$, hours worked are not perfect substitutes between sectors. Specifically, labour in the consumption and real estate sectors are imperfect substitutes which gives rise to sectoral wage differentials. In contrast, labour can freely move between commercial and residential real estate production within the construction sector where they face the same wage.

Households consume, accumulate houses, work for the consumption good and construction sector, and use bonds to smooth consumption. The flow of funds constraint for the household is given by

$$
C_{d, t}+q_{h d, t} H_{d, t}+\frac{S_{t}}{R_{t}} \leq q_{h d, t}\left(1-\delta_{h d}\right) H_{d, t-1}+w_{c, t} N_{c, t}+w_{h, t} N_{h c, t}+w_{h, t} N_{h d, t}+S_{t-1}+q_{l, t} L_{h d, t}^{e p}
$$

where $q_{h d, t}$ is the price of residential homes, $R_{t}$ is the gross real loan rate, and $w_{c, t}, w_{h}$ the real wage of the consumption good and construction sector respectively. $S_{t}$ is the loanable bond that the household buys in period $t$ which pays off in period $t+1$. Finally, $L_{h d, t}^{e p}$ is the amount of land that the household is left with after the depreciation of stock of residential real estate where $q_{l, t}$ is the land price. The household chooses $C_{d}, H_{d}, N_{c}, N_{h c}, N_{h d}$ and $S_{t}$ to maximize (1) subject to $(2)$.

\subsection{The Entrepreneur}

We model the entrepreneurial sector with borrowing constraints à la Iacoviello (2005), where entrepreneurs consume in every period and can raise their net worth by lowering their consumption. To introduce sectoral heterogeneity we consider a representative entrepreneur that operates in both the consumption good and the construction sector, where residential and commercial real estate are produced in the construction sector. The entrepreneur faces the utility function

$$
E_{t} \sum_{t=0}^{\infty} \beta_{e}^{t}\left(\log \left(C_{i, t}-\gamma_{e} C_{i, t-1}\right)\right), \quad i=c, h
$$

where $c$ and $h$ define the respective consumption good and construction good sectors. $C_{i, t}$ denotes the entrepreneur's consumption and $\gamma_{e}$ is the habit persistence parameter. We ensure that the parameter $\beta_{e} \in(0,1)$ is smaller than the households discount factor $\beta_{e}<\beta_{d}$, so that the credit constraint is binding in the steady state neighborhood (Iacoviello, 2005). The entrepreneur owns all inputs beside labour, i.e. capital, land and commercial real estate. 


\subsection{The Consumption Good Sector}

The entrepreneur in the consumption good sector produces goods using non-construction capital, non-construction labour and commercial real estate as inputs. The production function is given by

$$
Y_{t}=K_{c, t-1}^{\alpha_{c}} H_{c, t-1}^{\mu_{c}}\left(A_{c, t} N_{c, t}\right)^{1-\alpha_{c}-\mu_{c}}
$$

where $Y_{t}$ denotes output, $K_{c, t-1}, H_{c, t-1}, N_{c, t}, A_{c, t}$, denote non-construction capital, commercial real estate, labour and labour productivity, respectively. The entrepreneur is endowed with $K_{c, t-1}$ units of initial non-construction capital stock and $H_{c, t-1}$ of commercial real estate stock. Production functions in both sectors are subject to an exogenous labour-augmenting productivity shock. The shock process follows

$$
\ln A_{c, t}=\rho_{A_{c}} \ln A_{c, t-1}+\sigma_{A_{c}} \epsilon_{A_{c}, t}
$$

where $\sigma_{A c}$ is the standard deviations of the innovation, and $\epsilon_{A c, t}$ is an independent and identically distributed (i.i.d) normal process. The entrepreneur faces the flow of funds constraint

$$
\begin{aligned}
C_{c, t}+K_{c, t} & +q_{h c, t} H_{c, t}+w_{c, t} N_{c, t}+B_{c, t-1} \\
& =Y_{t}+\left(1-\delta_{k c}\right) K_{c, t-1}+\left(1-\delta_{h c}\right) q_{h c, t} H_{c, t-1}+\frac{B_{c, t}}{R_{t}}+q_{l, t} L_{h c, t}^{e p}-\phi_{c, t}{ }^{5}
\end{aligned}
$$

where $q_{h c, t}$ denotes the price of commercial real estate, the variable $\phi_{c, t}$ describes capital adjustment costs and $\delta_{k c}$ and $\delta_{h c}$ are the depreciation rates of non- construction capital and commercial real estate respectively. The value of land that the entrepreneur is left with after the depreciation of the housing stock is $q_{l, t} L_{h c, t}^{e p}$. Firms pledge the value of commercial real estate to finance investment (Chaney et al., 2012; Liu et al., 2013), where $B_{c, t}$ is the amount of debt used to finance investments in the non-construction sector which is subject to the credit constraint

$$
B_{c, t} \leq \rho_{b} B_{c, t-1}+\left(1-\rho_{b}\right) \theta_{c} E_{t}\left(q_{h c, t+1} H_{c, t}+K_{c, t}\right),
$$

where $\theta_{c}$ can be interpreted as a steady state loan-to-value (LTV) ratio, and $\rho_{b}$ measures the inertia in the borrowing limit (Iacoviello, 2015). Following Kiyotaki and Moore (1997) there is a limit on the obligations of entrepreneurs. The amount the creditor can borrow to invest is bounded by a fraction of the value of the collateral assets i.e. the commercial real estate and the non-construction capital. The entrepreneur in the consumption good sector chooses $\left\{C_{c, t}, K_{c, t}, H_{c, t}, N_{c, t}, B_{c, t}\right\}$ to maximize (3) subject to (4) - (6).

$$
{ }^{5} \phi_{c, t}=\frac{\phi_{k c}}{2}\left(\frac{k_{c, t}}{k_{c, t-1}}-1\right)^{2} k_{c, t-1}
$$




\subsection{The Construction Sector}

The entrepreneur in the construction sector produces new commercial and residential real estate using capital, labour and land as inputs (DiPasquale and Wheaton, 1994; DiPasquale, 1999; Mayer and Somerville, 2000). The production function for the former is given by

$$
I H_{c, t}=K_{h c, t-1}^{\alpha_{h}} L_{h c, t-1}^{\mu_{h}}\left(A_{h c, t} N_{h c, t}\right)^{1-\alpha_{h}-\mu_{h}},
$$

where $I H_{c, t}$ denotes the commercial real estate. Subscript hc and hd define the commercial and residential real estate sectors such that $K_{h c, t-1}, N_{h c, t}, L_{h c, t-1}$ denote the inputs; commercial real estate capital, labour and land that is used for commercial real estate, respectively. The production function for residential real estate is

$$
I H_{d, t}=K_{h d, t-1}^{\alpha_{h}} L_{h d, t-1}^{\mu_{h}}\left(A_{h d, t} N_{h d, t}\right)^{1-\alpha_{h}-\mu_{h}},
$$

where $I H_{d, t}$ denotes new homes, and $K_{h d, t-1}, N_{h d, t}$ and $L_{h d, t-1}$, are the corresponding inputs . $A_{h c, t}$ and $A_{h d, t}$ measure the productivity of commercial and residential construction and follow the processes

$$
\begin{aligned}
& \ln A_{h c, t}=\rho_{A_{h c}} \ln A_{h c, t-1}+\sigma_{A_{h c}} \epsilon_{A_{h c}, t} \\
& \ln A_{h d, t}=\rho_{h d} \ln A_{h d, t-1}+\sigma_{A h d} \epsilon_{A h d, t}
\end{aligned}
$$

where $\sigma_{A_{h c}}$ and $\sigma_{A h d}$ are the standard deviations of the innovation, and $\epsilon_{A_{h c}}$ and $\epsilon_{A h d, t}$ are two independent and identically distributed (i.i.d) normal processes. Construction sector entrepreneurs face the following flow of funds constraint

$$
\begin{aligned}
C_{h, t}+K_{h c, t}+K_{h d, t}+ & q_{l, t}\left(L_{h c, t}+L_{h d, t}\right)+w_{h, t}\left(N_{h c, t}+N_{h d, t}\right)+B_{h, t-1}=q_{h c, t} I H_{c, t} \\
& +q_{h d, t} I H_{d, t}+\left(1-\delta_{k h}\right) K_{h c, t-1}+\left(1-\delta_{k h}\right) K_{h d, t-1}+\frac{B_{h, t}}{R_{t}}-\phi_{h, t}{ }^{6},
\end{aligned}
$$

where $B_{h, t}$ is the debt for financing investments in the construction sector and is subject to the credit constraint

$$
B_{h, t} \leq \rho_{b} B_{h, t-1}+\left(1-\rho_{b}\right) \theta_{h} E_{t}\left(q_{l, t+1}\left(L_{h c, t}+L_{h d, t}\right)+K_{h c, t}+K_{h d, t}\right) .
$$

Land serves as a form of collateral for construction loans (Davis and Palumbo, 2008), so the amount the entrepreneur can borrow in the constructions sector is limited by the total value of land and construction capital in the production of real estate. The entrepreneur in the construction sector chooses $\left\{C_{h, t}, K_{h c, t}, K_{h d, t}, L_{h c, t}, L_{h d, t}, N_{h c, t}, N_{h d, t}, B_{h, t}\right\}$ to maximize (3) subject to $(7)-(10)$.

$$
{ }^{6} \phi_{h, t}=\frac{\phi_{h c}}{2}\left(\frac{k_{h c, t}}{k_{h c, t-1}}-1\right)^{2} k_{h c, t-1}+\frac{\phi_{h d}}{2}\left(\frac{k_{h d, t}}{k_{h d, t-1}}-1\right)^{2} k_{h d, t-1}
$$




\subsection{Market Clearing Conditions and Equilibrium}

The goods market produces consumption and business investment. The clearing condition implies that

$$
Y_{t}-\phi_{t}=C_{t}+I B_{t}
$$

where $C_{t}=C_{d, t}+C_{c, t}+C_{h, t}$ is the aggregate consumption and $I B_{t}$ is the business investment. Business investment is described as

$$
I B_{t}=I K_{c, t}+I K_{h, t}+q_{\bar{h}} I H_{c, t}
$$

where $I K_{c, t}=K_{c, t}-\left(1-\delta_{k c}\right) K_{c, t-1}$ can be described as investment in nonresidential equipment and intellectual property products. The second part of business investment $I K_{h, t}=K_{h c, t}-(1-$ $\left.\delta_{k h}\right) K_{h c, t-1}+K_{h d, t}-\left(1-\delta_{k h}\right) K_{h d, t-1}$ denotes the investment in construction machinery, which is a small part of the total machinery. CRE is used as an intermediate input in the production of consumption good output and built into the capital stock of the sector in the economy, hence the last term $q_{\bar{h}} I H_{c, t}$ describes the value of new RRE. The terms $H_{c, t}$ and $H_{d, t}$ evolve according to the

$$
I H_{c, t}=H_{c, t}-\left(1-\delta_{h c}\right) H_{c, t-1} .
$$

and

$$
I H_{d, t}=H_{d, t}-\left(1-\delta_{h d}\right) H_{d, t-1} .
$$

The GDP is the sum of the value added of the consumption good and residential real estate, given by

$$
G D P_{t}=Y_{t}+q_{\bar{h} d} I H_{d, t}
$$

Available land does not evolve over time (without loss of generality we can assume land to fixed at $\overline{L_{h}}=1$ ). In the spirit of Liu et al. (2013), we assume land market clears with the following condition

$$
\bar{L}_{h}=L_{h c, t}+L_{h d, t} .
$$

We define ex post land, $L_{h d}^{e p}$ and $L_{h c}^{e p}$ as the land which is owned by the respective household and entrepreneur following the depreciation of their housing stock. This is then purchased by the construction entrepreneur who uses it as an input. Since all land has a positive value it is always built upon when it becomes available, thus it follows that $L_{h c}^{e p}+L_{h d}^{e p}=\overline{L_{h}}$ with the following shares applied to each sector

$$
L_{h c, t}^{e p}=\frac{\delta_{h c} H_{c, t-1}}{\delta_{h c} H_{c, t-1}+\delta_{h d} H_{d, t-1}} \bar{L}_{h} \quad L_{h d, t}^{e p}=\frac{\delta_{h d} H_{d, t-1}}{\delta_{h c} H_{c, t-1}+\delta_{h d} H_{d, t-1}} \bar{L}_{h} .
$$




\subsection{Real Estate Substitution}

In this section, we use a static model to explain the mechanism of real estate substitution in the presence of a housing demand shock. Figure 4 includes the markets we consider in our analysis, namely the real estate, land and labour market. ${ }^{7}$

Consider a positive RRE price shock that shifts the demand curve in the RRE market from $D^{A}$ to $D^{B}$. Higher demand for houses will increase RRE prices $\left(q_{h d}\right)$ and cause RRE investment $\left(I H_{d}\right)$ to rise. To facilitate this increase in production, demand for construction machinery,

Figure 4 - Housing Demand Shock

Residential Real Estate Market

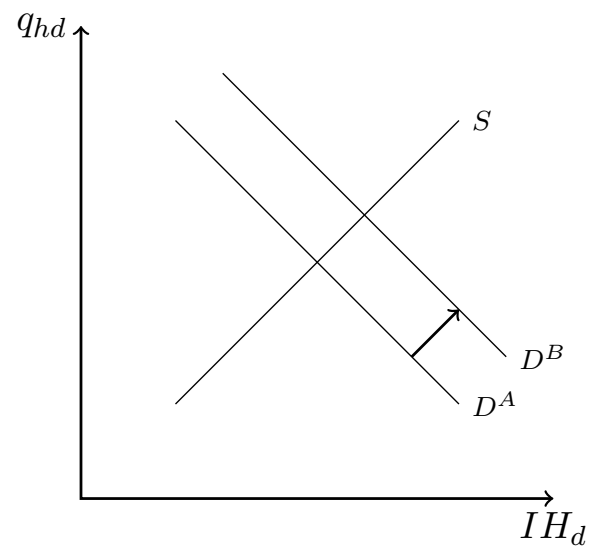

Labour Market (Construction)

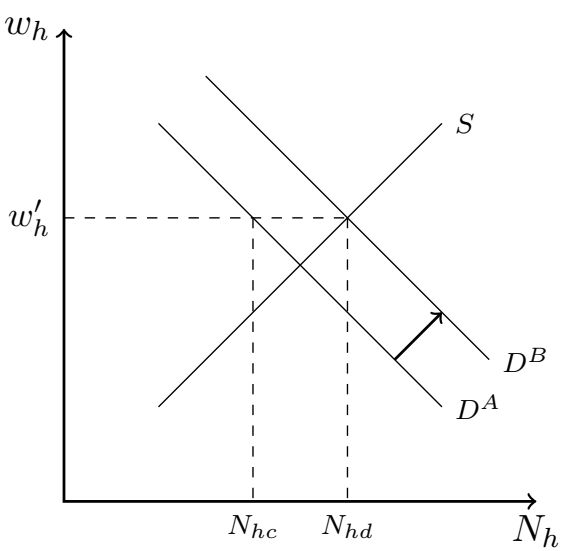

Land Market

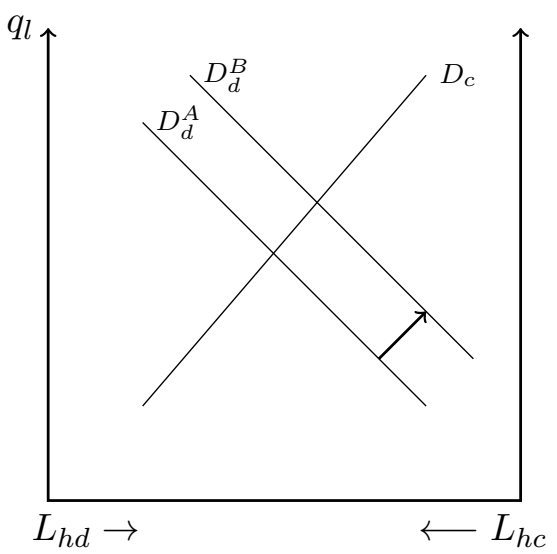

Commercial Real Estate Market

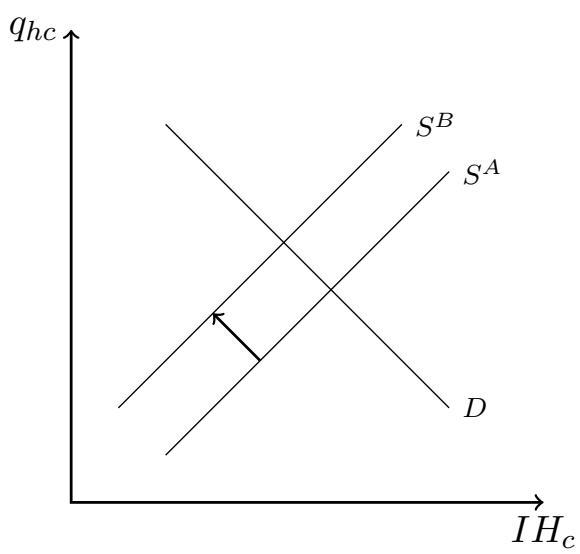

Notes: The figure display the residential real estate market (top left), the land market (top right), tha labour market (bottom left) and the commercial real estate market (bottom right), following a housing demand shock.

${ }^{7}$ For simplicity and to provide a clearer exposition of our results we don't explicitly refer to the the capital market in this section. 
labour in the construction sector $\left(N_{h d}\right)$, and land $\left(L_{h d}\right)$ will also increase. In the land market, the residential land demand curve will shift from $D_{d}^{A}$ to $D_{d}^{B}$, increasing competition for the available land, which leads to an increase in land prices $\left(q_{l}\right)$ and a substitution towards RRE land use. Similarly, the increased demand for labour for residential construction will raise construction sector wages $\left(w_{h}\right)$. This hike in construction costs generates a vertical shift in the supply of commercial real estate, displayed by the shift from $S^{A}$ to $S^{B}$ in the CRE market, which increase the CRE price $\left(q_{h c}\right)$, and cause a fall in CRE investment $\left(I H_{c}\right)$.

Thus real estate substitution following a RRE demand shock instigates cost push pressures which crowd out the CRE market in the same way as an adverse aggregate supply shock. ${ }^{8}$ As can be seen in Figure 4, the overall effects of real estate substitution on both real estate prices and investment depend upon the price elasticities of supply and demand in the real estate, land and labour markets. To shed further light upon the quantitative and state-contingent behaviour of this channel, we fully estimate the model in the following section.

\section{Estimation}

We use Bayesian methods to estimate our model. The posterior density is constructed by simulation using the Metropolis-Hastings algorithm (with 200,000 draws) as described in An and Schorfheide (2007). ${ }^{9}$ The model, due to the innate characteristics of an RBC model with no growth, can only allow for a limited number of shocks. Thus, since we cannot estimate a wide range of structural parameters, we focus our estimation strategy primarily on the shocks' processes. The model allows for six observables: consumption, RRE investment, RRE price, CRE investment, CRE price and total hours. All variables are denoted in real terms. All the data have been gathered from freely available sources such as BEA, BLS and FRED. We demean the hours and detrend the logarithm of the rest of the variables independently using a quadratic trend. ${ }^{10}$ The detrended and demeaned data are plotted in Figure 5. The sample covers the period from 1975:Q1 to 2019:Q4.

\footnotetext{
${ }^{8}$ There is a strand of literature in urban economics that indicate that the demand for both residential and commercial real estate are similar. In this framework introduced by Rosen (1979) and Roback (1982) land prices is the entry fee that households and firms must pay to access the productivity and the amenities of a labour market area. Because land is substitutable between uses, the price of both residential and commercial property will move together.

${ }^{9}$ Appendix C plots the prior and posterior densities, details on the estimation strategy and tests of convergence for the stability of the estimated parameters

${ }^{10}$ Appendix A describes further details of the data transformations.
} 

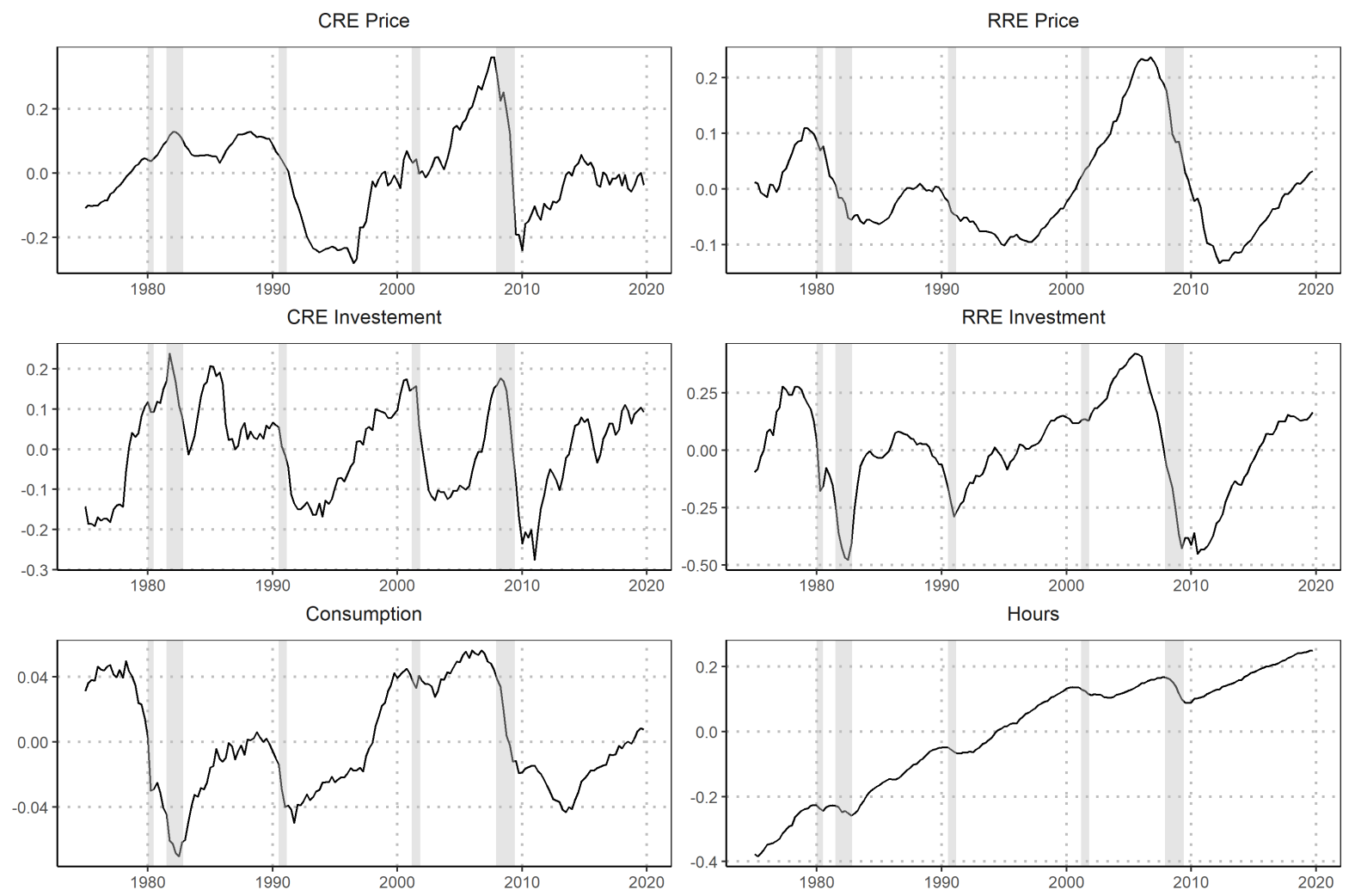

Notes: Prices, investment and consumption have been detrended using a quadratic trend and normalized to the beginning of the sample. Hours are demeaned. The sample period covers data from 1975Q1-2019Q4. Shaded regions indicate the NBER recession periods.

\subsection{Calibrated Parameters}

The calibrate the model over the US data between 1975-2019. Table 1 summarizes our calibration. We set the discount factor for households $\beta_{d}=0.9925$, that corresponds to a annual $3 \%$ bank prime loan rate. We fix the discount factor for entrepreneurs at $\beta_{e}=0.975$, which makes the credit constraint binding in the steady state (Iacoviello, 2005). We assume a higher degree of habit persistence for entrepreneurs $\gamma_{e}=0.65$ than households $\gamma_{d}=0.5$ in line with Liu et al. (2013). The depreciation rates for residential real estate, non construction capital, commercial real estate, and capital in the construction sector are set to $\delta_{h d}=0.01, \delta_{k c}=0.025$, $\delta_{h c}=0.025$ and $\delta_{k h}=0.04$ (Iacoviello and Neri, 2010). The parameter $\chi$ is pinned to 0.2 in order to target the data-implied steady state ratio of residential investment to output which equals $6 \%$. The parameter for labour mobility $\xi$ has been set to 0.65 according to Iacoviello and Neri (2010).

Real estate also typically accounts for about half of business assets, so we set $\alpha_{c}=0.20$ for the capital share and $\mu_{c}=0.20$ for the real estate share (Liu et al., 2013). It is important to 
Table 1 - Calibrated Parameter Values

\begin{tabular}{|c|c|c|c|c|c|}
\hline \multicolumn{3}{|c|}{ Households } & \multicolumn{3}{|c|}{ Entrepreneur } \\
\hline$\beta_{d}$ & Discount factor & 0.9925 & $\beta_{e}$ & Discount factor & 0.975 \\
\hline$\gamma_{d}$ & Habit persistence & 0.5 & $\gamma_{e}$ & Habit persistence & 0.65 \\
\hline$\chi$ & Housing services & 0.2 & $\rho_{b}$ & Borrowing inertia & 0.8 \\
\hline & Labour Mobility & 0.65 & & & \\
\hline \multicolumn{3}{|c|}{ Entrepreneur: Consumption Good } & \multicolumn{3}{|c|}{ Entrepreneur: Construction } \\
\hline$\alpha_{c}$ & Non-construction capital share & 0.2 & $\alpha_{h}$ & Construction capital share & 0.2 \\
\hline$\mu_{c}$ & Commercial real estate share & 0.2 & $\mu_{h}$ & Land share & 0.1 \\
\hline$\delta_{k c}$ & Depreciation of non-construction capital & 0.025 & $\delta_{h d}$ & Depreciation residential real estate & 0.01 \\
\hline$\delta_{h c}$ & Depreciation of commercial real estate & 0.025 & $\delta_{k h}$ & Depreciation of construction capital & 0.04 \\
\hline & LTV consumption good sector & 0.70 & $\theta_{h}$ & LTV construction sector & 0.5 \\
\hline
\end{tabular}

note that the construction sector is more labour-intensive, which means that the labour share ought to be larger than the equivalent in the consumption good sector. Thus the construction factor shares are set to $\alpha_{h}=0.20$ for the capital share and $\mu_{h}=0.1$ for the land share (Davis and Heathcote, 2005).

Finally, we consider the LTV ratios for commercial mortgage-backed securities loans in the consumption-good and the construction sector. If a property is intended to be an investment, usually it requires LTVs lower than $80 \%$. Furthermore, the value of LTV is heavily dependent on the liquidity of the asset that is used as collateral. Thus consumption good LTV is set to $70 \%\left(\theta_{c}=0.70\right),{ }^{11}$ while real estate firms correspond to an aggregate loan-to-value ratio of $50 \%$ $\left(\theta_{h}=0.5\right)$ in line with Gyourko (2009).

Table 2 shows the steady steady ratios of the model, which are in line with the US data over the sample period. The sum of the consumption share $(67 \%)$ and the business investment share $(27 \%)$ is the consumption good share, which amounts to $94 \%$. The remaining $6 \%$ is the residential real estate share. We split the business investment share into three sub-components, where commercial real estate accounts for $45 \%$, construction machinery accounts for $10 \%$, while the remaining $45 \%$ is software and non-construction capital. To calculate the business capital in the consumption good sector, we sum the capital used in the production of the consumption good and the commercial real estate wealth. The business capital for the construction good is $30 \%$ higher than the residential housing wealth, while the business capital of the construction is only $4 \%$ of the business capital stock. This means that construction firms possess only a small

\footnotetext{
${ }^{11}$ Grovenstein et al. (2005) measures LTV ratios to be $71.01 \%$ in five major commercial real estate property types originating from 10547 loans. Downing et al. (2008) report an average LTV of $67.40 \%$ for over 14.000 commercial mortgages between 1996 and 2005. Arsenault et al. (2013) finds a mean of $66 \%$ for the period of 1991 to 2011.
} 
Table 2 - Steady State Ratios

\begin{tabular}{llll}
\hline Variable & Interpretation & \multicolumn{2}{c}{ Value } \\
\hline$C / G D P$ & Consumption share & $67 \%$ & \\
$I B / G D P$ & Business investment share & $27 \%$ & \\
$-I K_{c} / I B$ & Software and equipment share & & $45 \%$ \\
$-I K_{h} / I B$ & Construction equipment share & & $10 \%$ \\
$-q_{h c} I H_{c} / I B$ & Commercial real estate share & & $47 \%$ \\
$q_{h d} I H_{d} / G D P$ & Residential real estate share & $6 \%$ & \\
$q_{h d} H_{d} / 4 \times G D P$ & Residential real estate wealth & 1.62 & \\
$\left(q_{c} H_{c}+K_{c}\right) / 4 \times G D P$ & Business capital consumption good & 2.38 & \\
$\left(K_{h c}+K_{h d)} / 4 \times G D P\right.$ & Business capital in construction & 0.16 & \\
\hline
\end{tabular}

proportion of total capital.

\subsection{Prior \& Posterior Distributions}

Table 3 summarizes the estimation of the model. We report the estimates of the shock and structural parameters at the posterior mean, median and mode, along with the $90 \%$ posterior probability intervals. For the shock processes, we use Beta distribution for the persistence with prior mean of 0.8 and a standard deviation of 0.1 , and Inverse-Gamma distribution for the standard errors with prior mean 0.001 and standard deviation 0.01.

In the construction sector, we observe that the autoregressive terms are relative high, indicating a persistent and prolonged effect on the construction technology, consistent with Iacoviello and Neri (2010). The standard errors are close at 0.027 and 0.03 for commercial and residential, respectively.

\section{Properties of the Model}

For the central part of the analysis, we focus on two shocks: an RRE preference shock and a technology shock to the consumption good sector. Impulse responses correspond to the median impulse response of a one standard deviation shock, alongside the $68 \%$ credibility intervals. The $y$-axis measures the deviation from the steady state. 
Table 3 - Prior and Posterior Distribution

\begin{tabular}{|c|c|c|c|c|c|c|c|c|}
\hline \multirow[b]{2}{*}{ Parameter } & \multicolumn{3}{|c|}{ Prior Distribution } & \multicolumn{5}{|c|}{ Posterior Distribution } \\
\hline & Density & Mean & SD & Mean & $5 \%$ & Median & Mode & $95 \%$ \\
\hline$\sigma_{z}$ & Inv Gamma & 0.00 & 0.00 & 0.047 & 0.042 & 0.047 & 0.046 & 0.052 \\
\hline$\sigma_{\chi}$ & Inv Gamma & 0.00 & 0.00 & 0.059 & 0.044 & 0.058 & 0.057 & 0.074 \\
\hline$\sigma_{\psi}$ & Inv Gamma & 0.00 & 0.00 & 0.014 & 0.012 & 0.014 & 0.014 & 0.015 \\
\hline$\sigma_{A c}$ & Inv Gamma & 0.00 & 0.00 & 0.023 & 0.021 & 0.023 & 0.023 & 0.026 \\
\hline$\sigma_{A h c}$ & Inv Gamma & 0.00 & 0.00 & 0.027 & 0.025 & 0.027 & 0.027 & 0.029 \\
\hline$\sigma_{A h d}$ & Inv Gamma & 0.00 & 0.00 & 0.03 & 0.027 & 0.03 & 0.03 & 0.033 \\
\hline$\rho_{z}$ & Beta & 0.80 & 0.01 & 0.77 & 0.74 & 0.77 & 0.77 & 0.8 \\
\hline$\rho_{\chi}$ & Beta & 0.80 & 0.01 & 0.96 & 0.95 & 0.96 & 0.96 & 0.98 \\
\hline$\rho_{\psi}$ & Beta & 0.80 & 0.01 & 0.99 & 0.98 & 0.99 & 0.99 & 0.99 \\
\hline$\rho_{A c}$ & Beta & 0.80 & 0.01 & 0.97 & 0.96 & 0.97 & 0.97 & 0.98 \\
\hline$\rho_{A h c}$ & Beta & 0.80 & 0.01 & 0.96 & 0.95 & 0.96 & 0.96 & 0.98 \\
\hline$\rho_{A h d}$ & Beta & 0.80 & 0.01 & 0.97 & 0.96 & 0.97 & 0.97 & 0.98 \\
\hline$\phi_{c}$ & Gamma & 10.00 & 6.25 & 18 & 14 & 17 & 17 & 21 \\
\hline$\phi_{h}$ & Gamma & 10.00 & 6.25 & 13 & 8.3 & 13 & 13 & 18 \\
\hline
\end{tabular}

\subsection{Estimated IRFs}

Figure 6 shows IRFs for the housing preference shock, which as explained in section 2.6 causes RRE prices and investment to increase. ${ }^{12}$ Increases in the production of residential real estate requires more inputs, thus increasing the land prices and wages in the construction sector, and therefore RRE investment itself. However, CRE production also requires these inputs, and it is the rise of these input prices that activate the real estate substitution channel and causes a fall in CRE investment.

In Iacoviello and Neri (2010) a positive housing preference shock creates a rise in capital in the construction sector and a decrease in capital in the consumption sector. This shift in resources between sectors causes a small but negative response to business investment. In our model, CRE investment by definition is included in the business investment; therefore with a reduction in CRE investment, business investment will follow. However, rather than a shift of resources between construction and non-construction capital, the redistribution takes place within the construction sector between the two types of real estate producers.

We generate a co-movement between RRE prices and consumption by utilising entrepreneurs'

\footnotetext{
${ }^{12}$ Alternatively this could be considered a "housing demand shock" as in Iacoviello and Neri (2010).
} 
Figure 6 - Housing Preference Shock
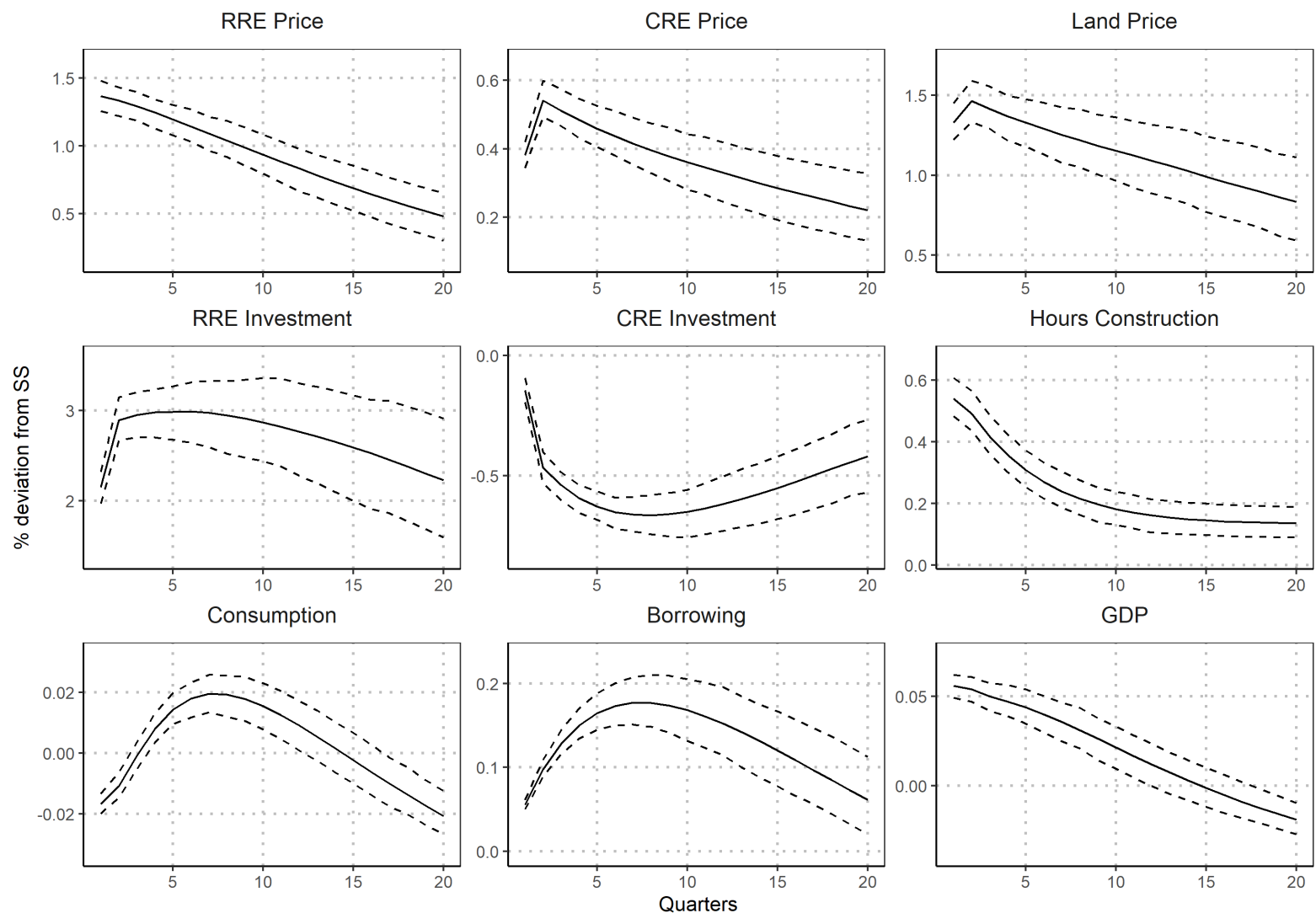

Notes: Impulse responses to a positive (one standard deviation) shock to housing preferences. The y-axis measures percent deviation from the steady state. Solid lines represent the median estimated responses and dashed lines demarcate the $68 \%$ credibility bands.

borrowing characteristic in the construction sector. The increase in RRE prices reduces household consumption; however, the rise in land prices raises the entrepreneurs' collateral capacity in the construction sector, allowing them to increase borrowing and consumption. Since entrepreneurs are impatient, they have a higher marginal propensity to consume, and the total consumption effects are positive. ${ }^{13}$ Finally, the presence of habits in entrepreneurs' utility function reinforces the intertemporal smoothing of consumption which creates the hump-shaped response in consumption.

Figure 7 shows the IRF for a technology shock in the consumption good sector. For a technology shock, investment and output go up on impact. However, with the separation of investment, we can observe that it is CRE investment that drives business investment, which in turn increases production and output, while RRE investment declines, by a smaller proportion,

\footnotetext{
${ }^{13}$ Berger et al. (2018) show that this positive co-movement depend on factors such as the level and distribution of debt, the size and history of house price shocks, and the level of credit supply.
} 
Figure 7 - Consumption Good Technology Shock
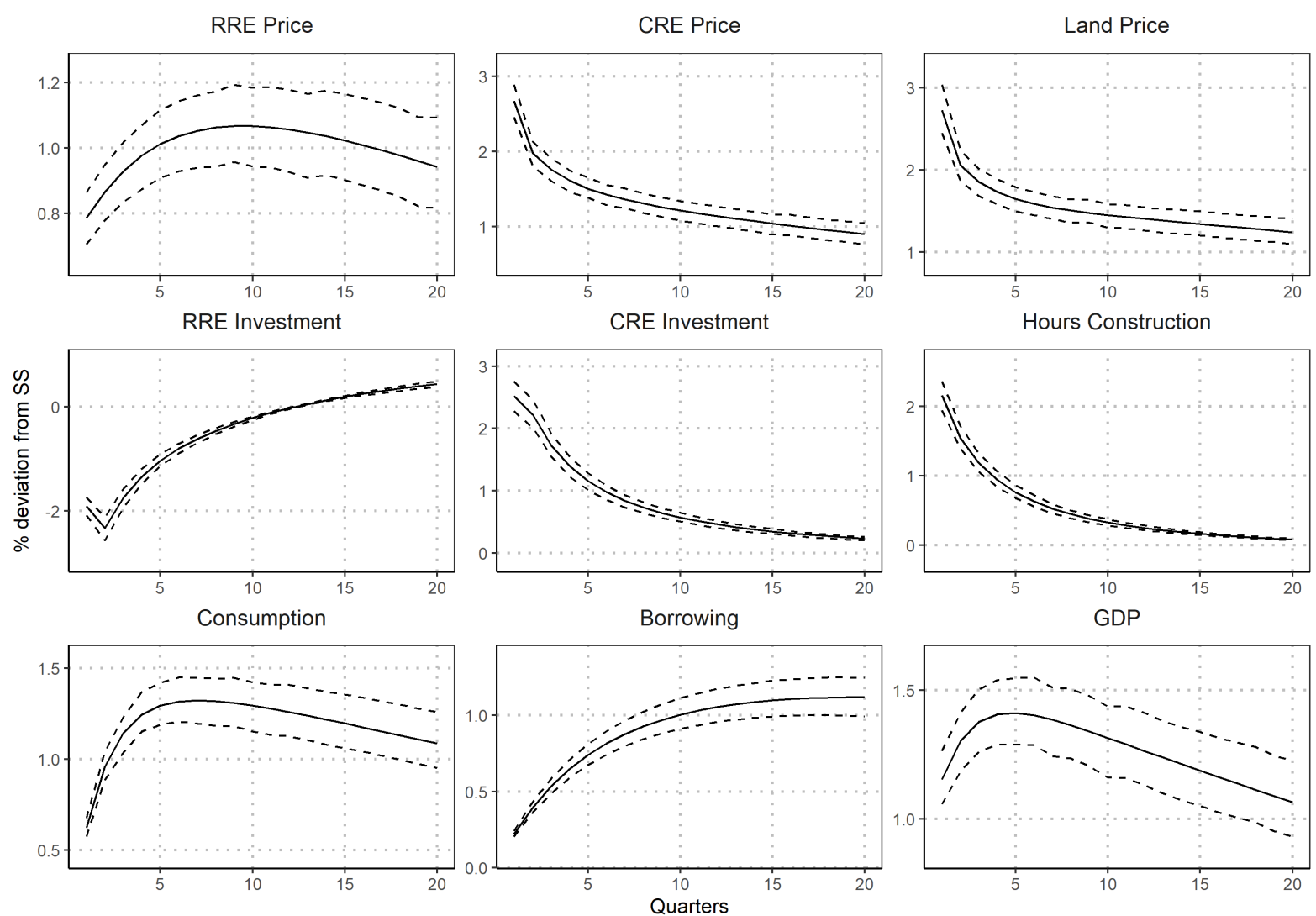

Notes: Impulse responses to a positive (one standard deviation) shock to consumption-good technology. The y-axis measures percent deviation from the steady state. Solid lines represent the median estimated responses and dashed lines demarcate the $68 \%$ credibility bands.

and overall output still increases.

Specifically, a positive productivity shock increases the demand and price of the inputs required to produce consumption goods; namely, consumption good capital, CRE capital and land. In turn, the increase in demand for CRE increases CRE investment, wages in the construction sector and land prices. Higher input prices set up the real estate substitution mechanism, which generates a cost-push increase in residential prices and reduces residential investment. Thus, what is initially perceived as a positive supply shock to the consumption good instigates the equivalent of a positive demand shock to CRE and, in turn, an adverse supply shock to residential property. Borrowing increases stem from the higher value of CRE and the increase in land prices. Consumption follows residential house prices very closely since household utility retains the same relative weights on housing and consumption. 


\subsection{Driving Forces of Real Estate Cycles}

Table 4 reports variance decomposition for the key variables in the real estate market across the 6 type of structural shocks at forecasting horizons between the impact period (1Q) and the five years after the initial shock (20Q).

It is clear that the largest variation in RRE prices stem from the housing preference shocks, especially at short horizons. Over longer horizons changes in household wealth through consumption technology shocks also play a significant role. CRE prices react in a analogous way. Specifically, over shorter horizons most of the variation is attributed to demand (consumption technology shock), while a greater weight is attached to supply (CRE technology shock) at longer horizons. Additionally, discount shocks play small but non-trivial role in determining property prices, which further highlights the importance of treating real estate and consumption separately.

More than half of the RRE investment variation is attributed to technology shocks to residential construction, and around a quarter of the variation is driven by housing demand shocks. On the other hand CRE investment on impact is primarily explained by technology shocks to the consumption good, i.e. CRE demand, and secondarily by technology shocks to commercial construction, i.e. CRE supply. At longer horizons this pattern is reversed with variation in supply, through CRE technology shocks, explaining the majority of the variation in CRE Investment.

To understand how our estimated model interprets specific movements of key variables in the real estate market, Figure 8 displays the historical decomposition of the prices and investment in residential and commercial real estate. The solid lines display the detrended historical data, obtained by applying a quadratic filter on the observed series. The filled regions show the historical contribution of housing preference, consumption technology and the two real estate technology shocks under our estimated parameters. In order to observe the real estate technology shock across the whole construction sector, we combine residential and commercial real estate technology shocks. The sum of these distortions accounts for a substantial variation in the filtered observed series. Furthermore, these four shocks highlight the contribution of changes in demand for each type real estate (housing preference and consumption technology shocks) and supply of real estate (real estate technology shocks) for the investment and price dynamics in the sector.

During a boom, new RRE demand pushes construction up (DiPasquale and Wheaton, 1994; Topel and Rosen, 1988), but also in our model CRE demand is able to increase construction activity. Thus the increase in real estate demand can either come from the demand side (preferences shock) or the supply side (consumption good technology shock) of the economy. In line with our estimated IRF's because of real estate substitution a positive shock to either housing preferences or consumption good technology will increase both real estate prices. However, the 
Table 4 - Variance Decomposition

\begin{tabular}{|c|c|c|c|c|c|c|}
\hline \multirow[b]{2}{*}{ Horizon } & \multicolumn{6}{|c|}{ Shocks } \\
\hline & Discount & $\begin{array}{c}\text { Housing } \\
\text { Preferences }\end{array}$ & $\begin{array}{l}\text { Labour } \\
\text { Supply }\end{array}$ & $\begin{array}{l}\text { Consumption } \\
\text { Technology }\end{array}$ & $\begin{array}{c}\text { CRE } \\
\text { Technology }\end{array}$ & $\begin{array}{c}\text { RRE } \\
\text { Technology }\end{array}$ \\
\hline \multicolumn{7}{|c|}{ RRE Prices } \\
\hline $1 \mathrm{Q}$ & 12.44 & 53.47 & 0.29 & 15.97 & 1.09 & 16.74 \\
\hline $5 \mathrm{Q}$ & 11.48 & 49.98 & 0.30 & 22.70 & 0.43 & 15.11 \\
\hline $10 \mathrm{Q}$ & 8.54 & 46.04 & 0.34 & 28.61 & 0.92 & 15.54 \\
\hline $20 \mathrm{Q}$ & 5.79 & 38.95 & 0.46 & 34.73 & 1.06 & 19.01 \\
\hline \multicolumn{7}{|c|}{ CRE Prices } \\
\hline $1 \mathrm{Q}$ & 9.94 & 0.99 & 1.24 & 58.67 & 28.22 & 0.94 \\
\hline $5 \mathrm{Q}$ & 13.21 & 2.69 & 0.73 & 46.38 & 34.44 & 2.54 \\
\hline $10 \mathrm{Q}$ & 10.23 & 3.24 & 0.62 & 44.56 & 38.38 & 2.97 \\
\hline $20 \mathrm{Q}$ & 7.58 & 3.58 & 0.58 & 43.51 & 41.66 & 3.10 \\
\hline \multicolumn{7}{|c|}{ RRE Investment } \\
\hline $1 \mathrm{Q}$ & 0.64 & 16.54 & 0.82 & 16.55 & 0.19 & 65.26 \\
\hline $5 \mathrm{Q}$ & 1.57 & 22.68 & 0.98 & 10.54 & 0.49 & 63.75 \\
\hline $10 \mathrm{Q}$ & 0.92 & 25.51 & 1.43 & 6.10 & 1.53 & 64.52 \\
\hline $20 \mathrm{Q}$ & 0.94 & 27.77 & 2.25 & 3.67 & 2.26 & 63.10 \\
\hline \multicolumn{7}{|c|}{ CRE Investment } \\
\hline $1 \mathrm{Q}$ & 3.59 & 0.59 & 12.51 & 53.73 & 28.95 & 0.63 \\
\hline $5 \mathrm{Q}$ & 6.95 & 3.44 & 10.02 & 32.31 & 43.90 & 3.38 \\
\hline $10 \mathrm{Q}$ & 4.18 & 4.84 & 9.41 & 21.11 & 55.87 & 4.59 \\
\hline $20 \mathrm{Q}$ & 2.65 & 5.67 & 9.72 & 14.20 & 62.69 & 5.06 \\
\hline
\end{tabular}

direction of the response of each element of investment will be contingent on the source the disturbance. Specifically, a positive housing preference shock boosts residential investment and diminishes commercial investment, while consumption good technology works in the opposite direction where residential investment falls and commercial investment increases. This can be seen in the bottom two graphs of Figure 8 where the property quantities (investments) of the two shocks work against each other. Thus to fully comprehend these investment cycles it is crucial that both specific demands and the relative demands of the two types of real estate are considered.

Increases in demand for RRE seems to be the main driver of the increase in RRE investment and prices in the build up to the 2007 financial crisis. Significantly, there is some suggestion of real estate substitution subduing CRE investment during this period, although the two series are both above their trend at the outbreak of the crisis. This co-movement is in contrast to the real estate substitution channel, and is also clearly displayed through a large fall in four series in the aftermath of the crisis. Whilst the reduction in residential demand explains some of the fall 
Figure 8 - Historical Decomposition of Structural Shocks
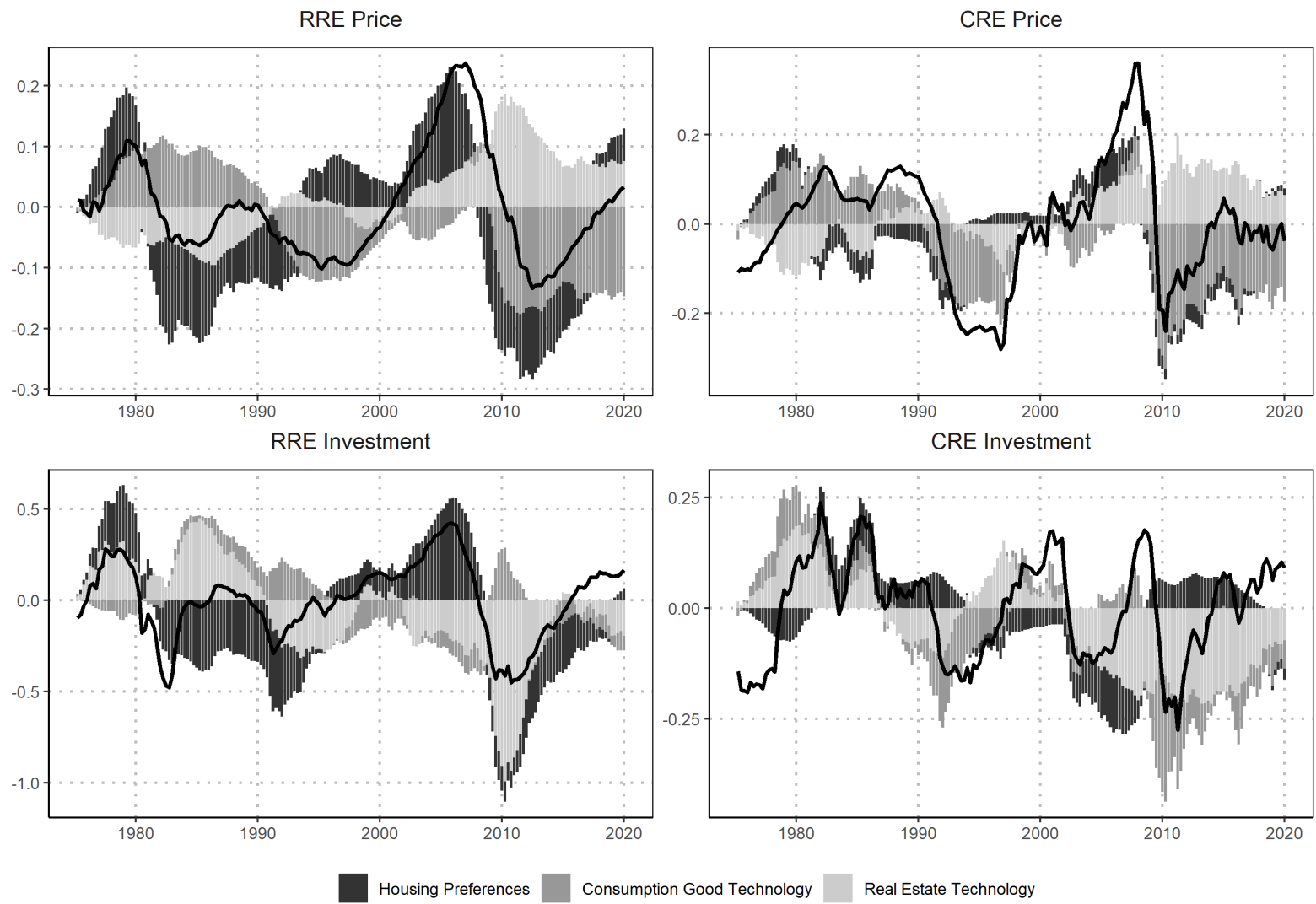

Notes: The solid line represents data. Housing preferences and consumption good technology include only their corresponding shock. Real estate technology shock includes both CRE and RRE technology shocks. All series are in deviation from the estimated trend.

in residential prices, the fall in commercial demand, by reducing land prices, played a significant role in explaining the price falls for both types of real estate.

Falls in the supply of real estate play a role in inflating real estate prices since 2001 and are the main drivers of the reduction in both types of real estate investment in the aftermath of the crisis which also acts to mitigate some of the collapse in prices. Moreover, in Figure 8 we observe that during this period both the supply for real estate, through negative real estate technology shocks and the demand for real estate, through negative consumption good technology and housing preference shocks, drive down real estate investment. Treated separately, all of these distortions cause both types of real estate investment to fall, with the construction sector responding to falls in GDP but also contributing to the fall in GDP through lower supply of real estate ${ }^{14}$. However, the relative falls in residential and commercial demand for real estate also matter

\footnotetext{
${ }^{14}$ Case et al. (2013) and Case and Quigley (2008) show how construction contributes to macroeconomic growth through the wealth and income effect in the USA.
} 
since unless equal, real estate substitution will take place. Specifically, there is a suggestion that whilst the reversal in the demand for RRE after the crisis prolonged the fall in RRE investment, because of real estate substitution it allowed CRE investment to recover much more quickly. In the following section, we detail the unique role that the construction sector, and its interaction with both land and the two types of real estate, plays in generating both of these investment co-movements.

\section{The Role of Land}

Land, while not directly useful as an input for consumption good producers or as a product for households, is a unique factor of production. Competition for land, stems from the fact that not only is land finite, ${ }^{15}$ but also both households and firms need it indirectly through their demands for new RRE and CRE respectively. Liu et al. (2013) were the first to introduce competition for land and a land reallocation channel in a DSGE framework. In their novel paper, they abstract from real estate production and a construction sector since land prices are able to capture the largest part of house price fluctuations (Davis and Heathcote, 2007) and display a clear co-movement with business investment. By omitting real estate production and the construction sector, land prices are identical to property prices, and guarantee that a land reallocation channel will always be present and dominant. However, as shown by Davis (2009) the price and quantity of land in residential use has very different time-series properties than the price and quantity of land in commercial use.

A key message of our paper is that there is a clear distinction between land and real estate. As described by Davis and Heathcote (2007); Davis and Palumbo (2008) and Nichols et al. (2013), real estate can be viewed as bundle of structures and land. Since land use is not observed directly and the land measurement is indistinguishable from real estate, land values can also be conceptualised as the value of the real estate when you exclude the cost of the structures. The estimated land value in Davis and Heathcote (2007) is constructed from the residential real estate value minus the replacement cost of residential structures. In contrast, whilst we do not utilise data on the replacement cost of structures, both residential and commercial real estate values and their interaction through the real estate substitution channel contribute to our measure. In Figure 9 we compare the aggregate land price from our model with the estimated residential land price from Davis and Heathcote (2007). Despite the different approaches both measures capture the persistent upward trend from the late 1990's, subsequent fall after 2007 and the recent recovery. Moreover, given that changes in RRE prices drove land price movements during

\footnotetext{
${ }^{15}$ Land can grow at a very small rate if we consider the land zoning restriction lifts, that enable the commercial and residential building to overtake farmlands or previously unzoned territories
} 
this period, one would expect the two series to move more closely together. Nevertheless the pre-crisis peak land price in our model is significantly lower than that of Davis and Heathcote (2007). As was shown in Figure 8, real estate substitution meant that there was a crowding out of CRE investment due to the increased RRE demand. Moreover, by increasing the residential / commercial land shares in the construction sector the relative increase in the supply of RRE offsets some of the land price increase. The contribution of fluctuations in CRE demand to land prices can also be seen through the additional fluctuations before 1990 and a later peak of the and price during the start of the financial crisis period.

\subsection{Land Shares and Investment}

To understand the role of land shares and its relationship with real estate investment we examine the simulated path of investment and land share for both residential and commercial real estate. Figure 10 displays the simulated path of RRE investment and residential land in the top panel, and the CRE investment and commercial land in the bottom panel. Land and investment cycles seem to be in synchronisation for most of the sample, however, there are significant divergences, in particular following recession periods.

For example, following the office overbuilding of the 1980s there is substitution away from

Figure 9 - Land Prices

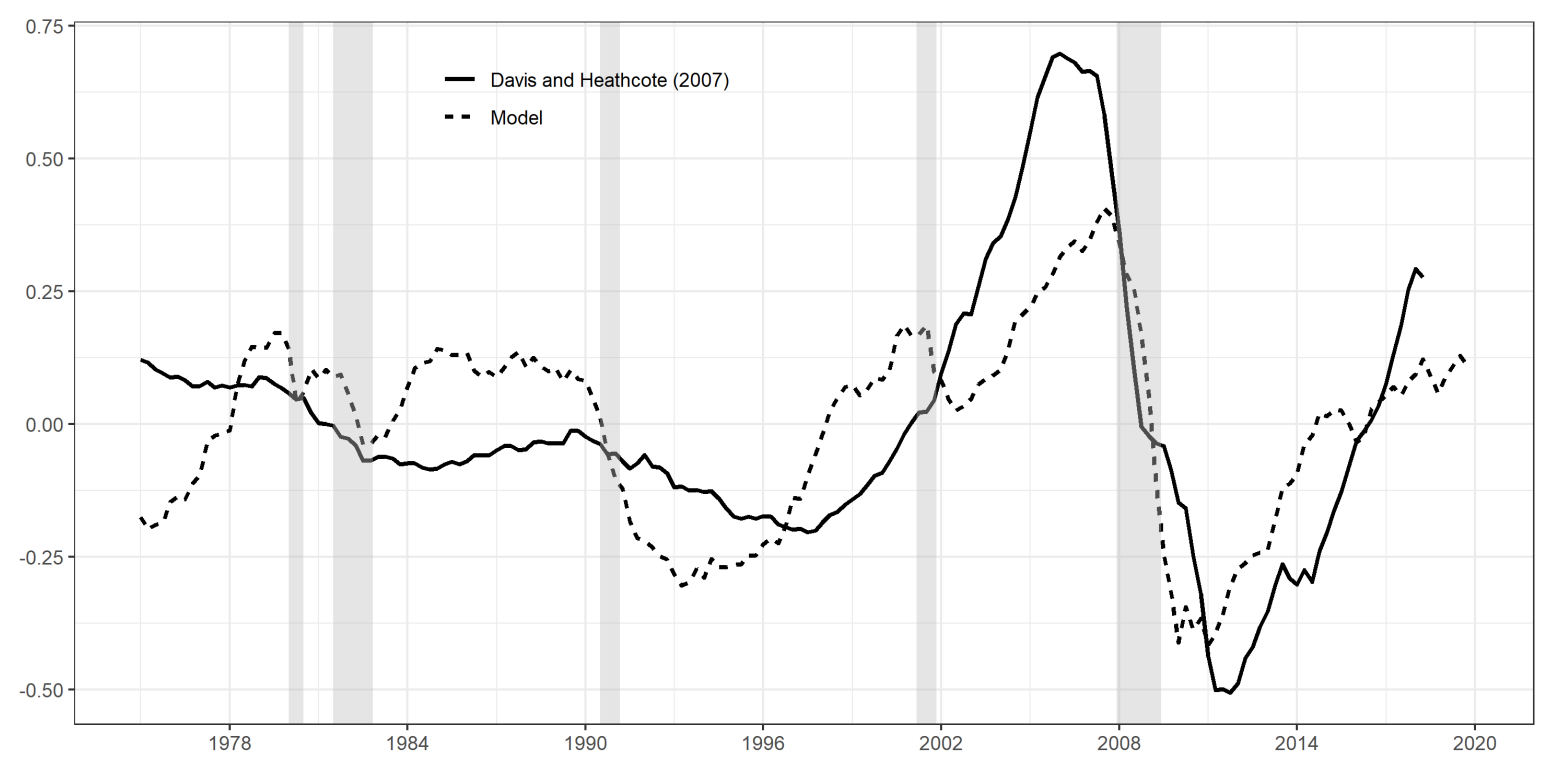

Note: Real land price represents constant-quality price index for the aggregate stock of residential land in the United States estimated by Davis and Heathcote (2007). Source: https://www.aei.org/historical-land-priceindicators/. 
Figure 10 - Land Share and Investment
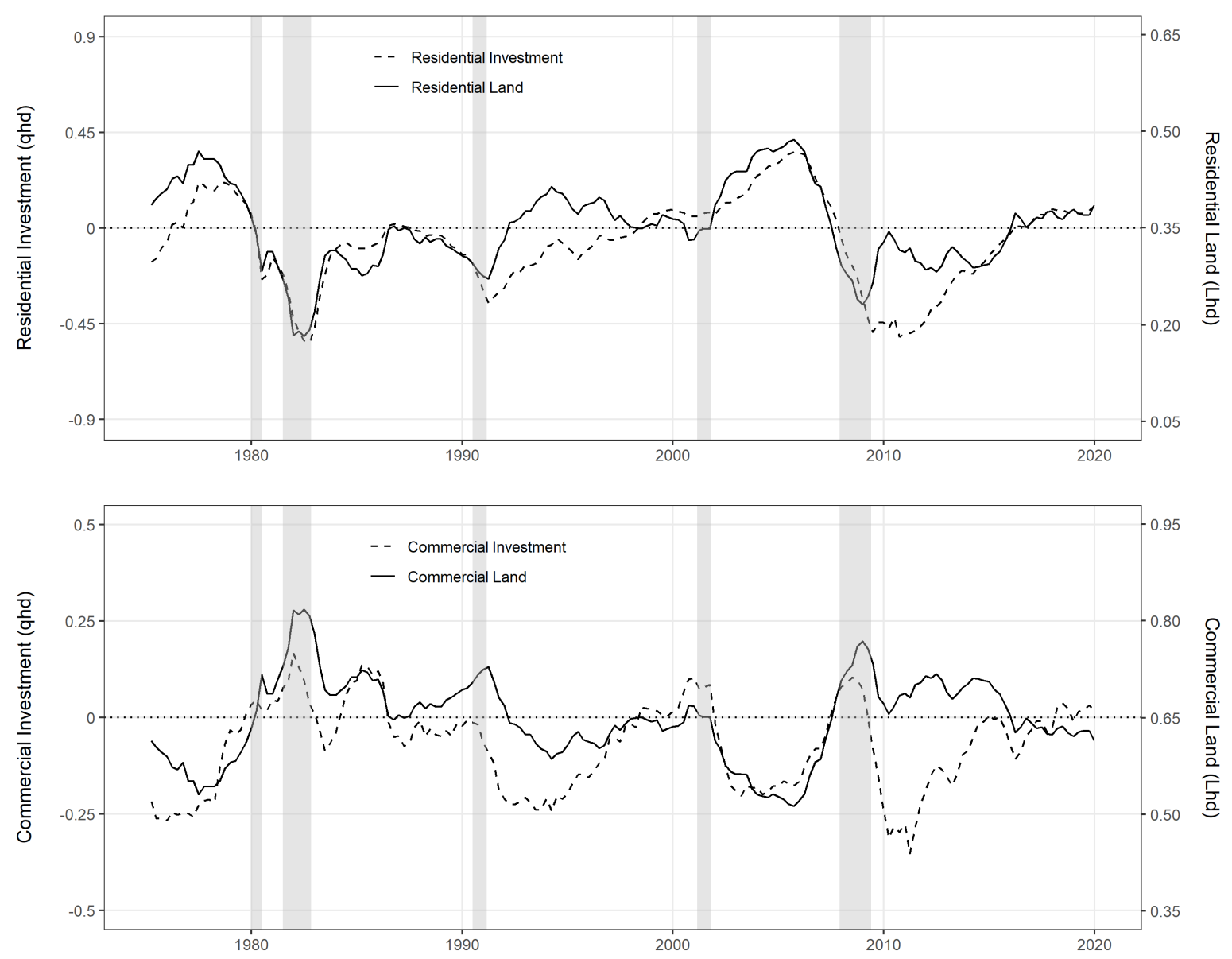

Notes: Top figure display residential investment (solid line) and residential land (dashed line). The bottom figure displays commercial investment (solid line) and commercial land (dashed line). The sum of land is always one. Investment is measured on the left axis and land shares on the right. The shaded bars mark the NBER recession dates.

commercial land use towards residential which peaks in 2007. However, post-2007 we observe a large shift that changes the composition of land share towards the commercial side. At the same time we can observe movements in investment that are not associated with an equivalent reallocation of the supply of land. Specifically, during the post-financial crisis recession, we see a significant and persistent fall in both RRE and CRE investment that is not attributed to the substitution of land. Using land as the only input in the construction sector, the positive co-movements between RRE investment, CRE investment and GDP would be missing and the supply real estate would be significantly overestimated. 


\subsection{Land as a Unique Input}

To understand the relationship between land and real estate in our framework more clearly, consider the construction sector's demand for land, which for RRE and CRE production is given by

and

$$
q_{l, t}=\beta_{e} E_{t} \frac{u_{c h, t+1}}{u_{c h, t}}\left(\mu_{h} \frac{q_{h c, t} I H_{c, t+1}}{L_{h c, t}}\right)+\lambda_{b h, t}\left(1-\rho_{b}\right) \theta_{h} q_{l, t+1}
$$

$$
q_{l, t}=\beta_{e} E_{t} \frac{u_{c h, t+1}}{u_{c h, t}}\left(\mu_{h} \frac{q_{h d, t} I H_{d, t+1}}{L_{h d, t}}\right)+\lambda_{b h, t}\left(1-\rho_{b}\right) \theta_{h} q_{l, t+1}
$$

respectively. The term $u_{c h}$ is the marginal utility of consumption and $\lambda_{b h}$ defines the shadow value of the construction sectors existing loans in consumption units. Like Liu et al. (2013) according to equations (17) and (18) the cost of a unit of land depends upon the marginal utility of land services and the discounted resale value of land. However, the marginal product of land,

$\left(\mu_{h} \frac{I H_{d, t+1}}{L_{h d, t}}\right.$ and $\left.\mu_{h} \frac{I H_{c, t+1}}{L_{h c, t}}\right)$ depends upon the real estate demands of the construction sector and not directly on the demands of households or consumption good producers.

At the extreme when $\mu_{h} \rightarrow 1$ in production functions of RRE and CRE ((7) and (8) respectively), the construction of real estate requires only land, so that the construction sector becomes redundant. The supply of new structures is constant, and land and real estate are equivalent, so that akin Liu et al. (2013) the change in RRE investment perfectly offsets the change in CRE investment, to equate the marginal product of land in each sector.

In our framework, the land reallocation channel is encapsulated through a broader definition of competition in the construction sector, where the competition between households and firms is not for land use but for the two types of real estate. Land reallocation is always present, but in comparison with Liu et al. (2013) it is not always dominant. A critical motivation behind a more flexible version of real estate substitution is that, as we have seen in Figure 10, the two types of real estate do not always follow an opposing path. In particular, following the financial crisis, RRE, CRE and GDP saw significant falls so an assumption of complete substitution between the two types of real estate would be unreasonable. The recent global Covid-19 pandemic has further underscored the importance of this model feature. The restrictions of workers to attend offices and hospitality venues has had severe implications for both the supply of labour, the value of commercial premises, and in-turn commercial real estate investment. On the other hand, the implications for residential real estate investment depend upon changes in both the demand for residential property and all of the inputs required for production in the construction sector. To shed further light on this issue we consider a labour supply shock.

Our motivation for introducing a labour supply shock is twofold. Firstly, it clearly displays the mechanism behind the real estate investment co-movements in our flexible version of real 
Figure 11 - Labour Supply Shock and Land Share
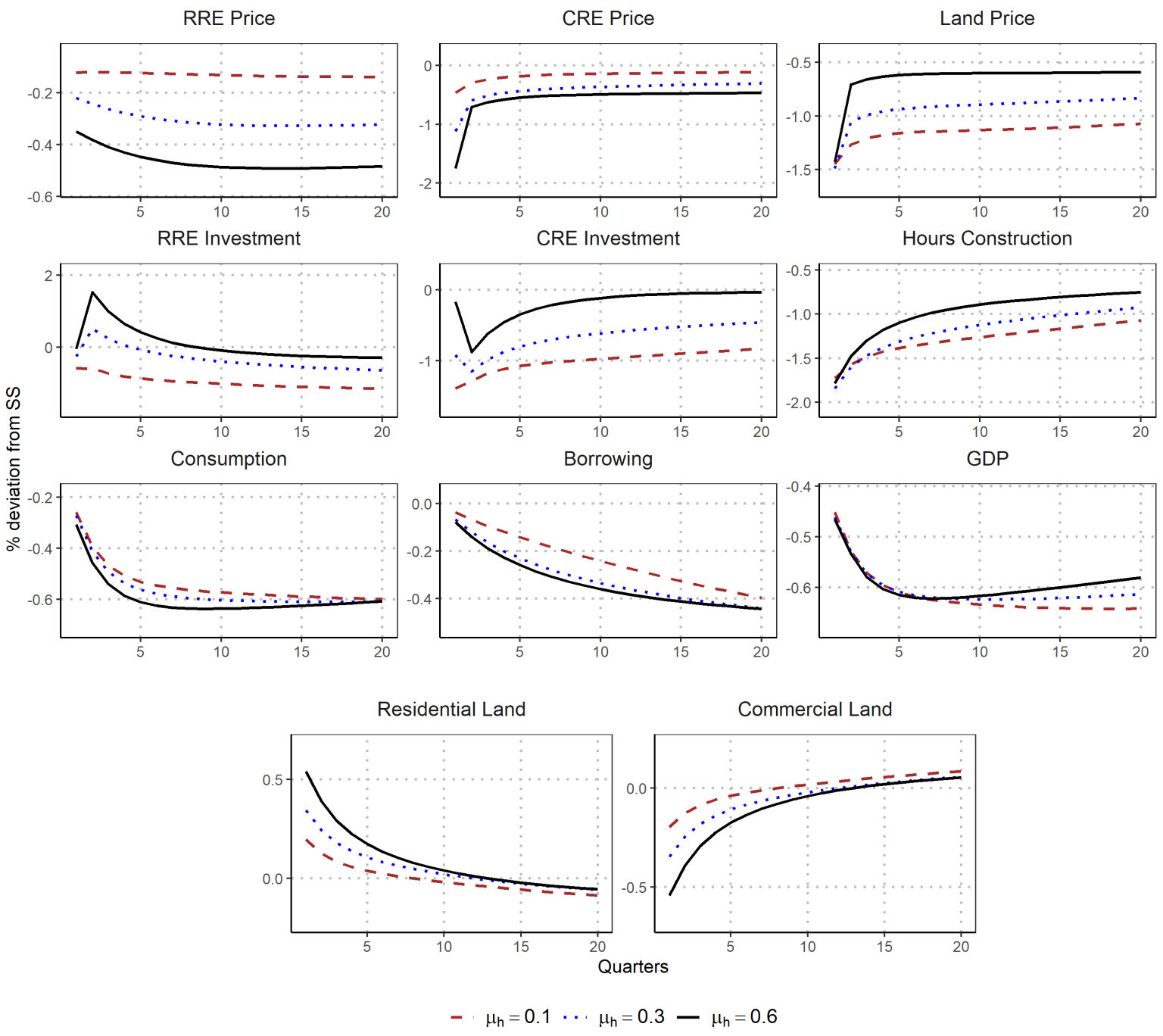

Notes: Impulse responses to a positive (one standard deviation) shock to labour supply. The y-axis measures percent deviation from the steady state.

estate substitution. Secondly, labour supply shocks have been shown to be a significant driver of the fall in labour hours during the Covid-19 pandemic (Brinca et al., 2020). ${ }^{16}$ We argue that such a fall in labour supply will unmistakably leads to a fall in CRE investment as the marginal product of CRE falls. However the implications for RRE investment are ambiguous and contingent upon the weight that land has relative to the other inputs required for the

\footnotetext{
${ }^{16}$ For tractability we assume that the labour supply shock falls uniformly across our sectors. As argued by Dingel and Neiman (2020), the extent to which work in a sector can be carried out at home would have implications for our model, both for the sectoral response of hours, but also because it creates a separation between labour and CRE in production. In our model this would create a cushioning of the falls in labour supply alongside an amplification of the fall in CRE investment and real estate substitution
} 
construction of real estate. With a construction sector, where the creation of structures is given by equations (7) and (8), we have that land, capital and labour all contribute to the formation of new real estate. As a result, the fall in the supply of labour in Figure 11 with low values of $\mu_{h}$ not only reduces the demand for $I H_{c, t}$ from consumption good producers but also the supply of both labour and capital to the whole of the construction sector. This creates a separation of real estate investment from land use which can be seen by equating (17) and (18) to give

$$
I H_{d, t+1}=\frac{q_{h d, t} L_{h d, t}}{q_{h c, t} L_{h c, t}} I H_{c, t+1} .
$$

In (19) RRE investment dynamics are not only determined by the ratio of land, but also by the demand for commercial real estate. This separation of $I H_{c, t}$ from $L_{h c, t}$ allows $I H_{d, t}$ to potentially fall, despite a reallocation of land towards the residential sector $\left(\frac{L_{h d, t}}{L_{h c, t}}\right.$ increases $)$ which allows for both CRE and RRE investment to co-move such that the aggregate supply of real estate falls. Moreover, as can be seen in equations (17) and (18) and in Figure 11, with lower values of $\mu_{h}$ falls in the land price have less influence on construction costs and the real estate substitution channel is weakened which suppresses some of the falls RRE and CRE prices. Furthermore, driven by the reduction in labour hours, lower consumption and lower GDP, the demands for both $\mathrm{CRE}$ and $\mathrm{RRE}\left(q_{h d, t} I H_{d, t+1}\right.$ and $q_{h c, t} I H_{c, t+1}$ respectively) are less. Whilst, by assumption, the supply of land is fixed, the inputs of labour and capital can fall such that both commercial and residential real estate investment fall. This further reduces the marginal product of land,which causes land prices to become more volatile. In contrast for higher values of $\mu_{h}$, land reallocation is the main driver of real estate investment such that the real estate substitution channel dominates and the two series take opposing paths.

\section{Conclusion}

This paper introduces a construction sector into a macroeconomic framework to explain the comovements of property prices and the substitution of commercial and residential real estate investment that we observe in the data. We refer to this mechanism as "real estate substitution", where the inputs of real estate production and the source of macroeconomic fluctuations play a significant role in determining both the direction and magnitude of construction sector dynamics. Specifically, real estate substitution encapsulates land reallocation, but it does not impose strict substitution between the two types of real estate. This additional degree of flexibility is crucial to explain the large fall in both residential and commercial real estate, which was observed during the financial crisis.

Contrary to the traditional view of the business cycle literature, our sectoral macroeconomic model allows us to identify the interactions within the real estate market and the propagation 
mechanism. We give a unique interpretation to the housing preference shock, where it does not merely generate a shift in the preference for residential real estate, instead, it is shown to have a structural connection with commercial real estate and the consumption-good sector. In turn, this relationship explains how demand shocks in residential real estate can easily crowd out commercial real estate, which affects the goods market in a similar way to an adverse aggregate supply shock.

The Covid-19 pandemic has significantly affected the real estate market and further highlighted the importance of a macroeconomic framework that can capture the interactions and dynamics of the real estate market. Because of health concerns, a stay-at-home order has been issued, which has substantially shifted the working model of the labour market. A new convention has arisen where people have either been forced or have chosen to work from home. At the same time, business unable to operate remotely have been extremely adversely affected. Thus, the degree to which producers can substitute commercial real estate for residential real estate is crucial for both aggregate productivity and the relative real estate demand. The extent to which these changes are made permanent will become clearer in the post pandemic world. Nevertheless, consideration of this new role of residential real estate where it is not only used for consumer consumption but also aids production as a place of work is an interesting avenue for future research. 


\section{Appendix A: Data and Sources}

Aggregate Consumption: Real Personal Consumption Expenditure (seasonally adjusted, chain-type quantity index, base year 2009, table 1.1.3) divided by the Civilian Noninstitutional Population (CNP16OV, source: Bureau of labour Statistics). Source: Bureau of Economic Analysis (BEA)

Business Investment: Real Private Nonresidential Fixed Investment (seasonally adjusted, chain-type quantity index, base year 2009, table 1.1.3) divided by CNP16OV. Source: BEA

Residential Investment Real Private Residential Fixed Investment (seasonally adjusted, chain-type quantity index, base year 2009, table 1.1.3) divided by CNP16OV. Source: BEA

Commercial Real Estate Investment Real Private Nonresidential Structures Fixed Investment (seasonally adjusted, chain-type quantity index, base year 2009, table 1.1.3) divided by CNP16OV. Source: BEA

Residential Real Estate Prices : Real House Price Index, United States (NSA) deflated with the implicit price deflator for the nonfarm business sector (table 2 , source: BLS). Source: Census Bureau

Commercial Real Estate Prices : Real Commercial Real Estate Price Index, United States (NSA) deflated with the implicit price deflator for the nonfarm business sector (table 2, source: BLS). The CRE price level index is a weighted-average of three appraisal-based commercial property price per square foot series, office property, retail property, and warehouse/industrial property, from NREI. Source: Federal Reserve System

Total Hours: Hours of Wage and Salary Workers on Nonfarm Payrolls: Private (seasonally adjusted, Billions of Hours, Series ID: PRSCQ). Source: FRED 


\section{References}

An, S. and Schorfheide, F. (2007). Bayesian Analysis of DSGE Models. Econometric Reviews, 26(2-4):113-172.

Arsenault, M., Clayton, J., and Peng, L. (2013). Mortgage Fund Flows, Capital Appreciation, and Real Estate Cycles. Journal of Real Estate Finance and Economics, 47(2):243-265.

Bahaj, S., Foulis, A., and Pinter, G. (2020). Home values and firm behavior. American Economic Review, 110(7):2225-70.

Benhabib, J., Rogerson, R., and Wright, R. (1991). Homework in Macroeconomics: Household Production and Aggregate Fluctuations. Journal of Political Economy, 99(6):1166-1187.

Berger, D., Guerrieri, V., Lorenzoni, G., and Vavra, J. (2018). House prices and consumer spending. The Review of Economic Studies, 85(3):1502-1542.

Boldrin, M., Garriga, C., Peralta-Alva, A., Sánchez, J. M., et al. (2013). Reconstructing the great recession. Federal Reserve Bank of St. Louis, Research Division.

Brinca, P., Duarte, J. B., and Faria-e Castro, M. (2020). Measuring sectoral supply and demand shocks during covid-191. Covid Economics, page 147.

Case, K. E., Glaeser, E. L., and Parker, J. A. (2000). Real estate and the macroeconomy. Brookings Papers on Economic Activity, 2000(2):119-162.

Case, K. E. and Quigley, J. M. (2008). How housing booms unwind: income effects, wealth effects, and feedbacks through financial markets. European Journal of Housing Policy, 8(2):161180.

Case, K. E., Quigley, J. M., Shiller, R. J., et al. (2013). Wealth effects revisited 1975-2012. Critical Finance Review, 2(1):101-128.

Chaney, T., Sraer, D., and Thesmar, D. (2012). The collateral channel: How real estate shocks affect corporate investment.

Chang, Y. (2000). Comovement, excess volatility, and home production. Journal of Monetary Economics, 46(2):385-396.

Davis, M. A. (2009). The price and quantity of land by legal form of organization in the United States. Regional Science and Urban Economics, 39(3):350-359.

Davis, M. A. and Heathcote, J. (2005). Housing and the Business Cycle. International Economic Review, 46(3):751-784. 
Davis, M. A. and Heathcote, J. (2007). The price and quantity of residential land in the United States. Journal of Monetary Economics, 54(8):2595-2620.

Davis, M. A. and Palumbo, M. G. (2008). The price of residential land in large US cities. Journal of Urban Economics, 63(1):352-384.

Dingel, J. and Neiman, B. (2020). How many jobs can be done at home? Covid Economics, page 16.

DiPasquale, D. (1999). Why don't we know more about housing supply? The Journal of Real Estate Finance and Economics, 18(1):9-23.

DiPasquale, D. and Wheaton, W. C. (1994). Housing market dynamics and the future of housing prices. Journal of Urban Economics, 35(1):1-27.

Doan, T., Litterman, R., and Sims, C. (1984). Forecasting And Conditional Projection Using Realistic Prior Distributions. Econometric Reviews, 3(1):1-100.

Downing, C., Stanton, R., and Wallace, N. (2008). Volatility, mortgage default, and cmbs subordination. University of California, Berkeley.

Fisher, J. D. M. (2007). Why Does Household Investment Lead Business Investment over the Business Cycle? Journal of Political Economy, 115(1):141-168.

Glaeser, E. L. and Ward, B. A. (2009). The causes and consequences of land use regulation: Evidence from Greater Boston. Journal of Urban Economics, 65(3):265-278.

Greenwood, J. and Hercowitz, Z. (1991). The Allocation of Capital and Time over the Business Cycle. Journal of Political Economy, 99(6):1188.

Grovenstein, R. A., Harding, J. P., Sirmans, C., Thebpanya, S., and Turnbull, G. K. (2005). Commercial mortgage underwriting: How well do lenders manage the risks? Journal of Housing Economics, 14(4):355-383.

Gyourko, J. (2009). Understanding Commercial Real Estate: How Different from Housing Is It? Journal of Portfolio Management, 35:23-+.

Gyourko, J., Mayer, C., and Sinai, T. (2013). Superstar cities. American Economic Journal: Economic Policy, 5(4):167-199.

Head, A., Lloyd-Ellis, H., and Sun, H. (2014). Search, liquidity, and the dynamics of house prices and construction. American Economic Review, 104(4):1172-1210. 
Horvath, M. (2000). Sectoral shocks and aggregate fluctuations. Journal of Monetary Economics, 45(1):69-106.

Iacoviello, M. (2005). House prices, borrowing constraints, and monetary policy in the business cycle.

Iacoviello, M. (2015). Financial business cycles. Review of Economic Dynamics, 18(1):140-163.

Iacoviello, M. and Neri, S. (2010). Housing market spillovers: Evidence from an estimated DSGE model. American Economic Journal: Macroeconomics, 2(2):125-164.

Kiyotaki, N. and Moore, J. (1997). Credit Cycles. Journal of Political Economy, 105(2):211-248.

Lally, P. (2009). How BEA Accounts for Investment in Private Structures. Survey of Current Business. US Bureau of Economic Analysis, 89(2):9-15.

Leamer, E. E. (2015). Housing really is the business cycle: what survives the lessons of 2008-09? Journal of Money, Credit and Banking, 47(S1):43-50.

Litterman, R. B. (1986). Forecasting with Bayesian Vector Autoregressions: Five Years of Experience. Journal of Business $\&$ Economic Statistics, 4(1):25.

Liu, Z., Wang, P., and Zha, T. (2013). Land-Price Dynamics and Macroeconomic Fluctuations. Econometrica, 81(3):1147-1184.

Mayer, C. J. and Somerville, C. T. (2000). Residential construction: Using the urban growth model to estimate housing supply. Journal of urban economics, 48(1):85-109.

Nelson, T. R., Potter, T., and Wilde, H. H. (2000). Real estate assets on corporate balance sheets. Journal of Corporate Real Estate, 2(1):29-40.

Nichols, J. B., Oliner, S. D., and Mulhall, M. R. (2013). Swings in commercial and residential land prices in the United States. Journal of Urban Economics, 73(1):57-76.

Roback, J. (1982). Wages, Rents and the Quality of Life. Journal of Political Economy, 90(6):1257-1278.

Rosen, S. (1979). Wage-based indexes of urban quality of life. In Current issues in urban economics, pages 74-104. Johns Hopkins Univ. Press.

Topel, R. and Rosen, S. (1988). Housing investment in the united states. Journal of political Economy, 96(4):718-740.

Wheaton, W. C. (1999). Real estate "cycles": Some fundamentals. Real Estate Economics, 27(2):209-230. 